\title{
İşletme Sermayesinin Makroekonomik Belirleyicileri: BiST'te Sektörler Arası Bir Karşılaştırma ${ }^{1}$
}

Veli AKEL

Doç. Dr., Erciyes Üniversitesi iiBF, İşletme Bölümü

veliakel@erciyes.edu.tr

Yüksel ILTAŞ

Öğr. Gör. Dr., Ahi Evran Üniversitesi

Çiçekdağı MYO

iltasyuksel@gmail.com

İşletme Sermayesinin Makroekonomik
Belirleyicileri: BiST'te Sektörler Arası Bir
Karşıllaştırma

Özet

$\mathrm{Bu}$ çalışmanın amacı, temel makroekonomik göstergelerin metal, gıda, kimya, tekstil ve teknoloji sektörlerinin işletme sermayesi üzerindeki etkisini analiz etmek ve sektörler arasında bir karşılaştırma yapmaktır. Bu kapsamda, gayrisafi yurtiçi hâsıla, sanayi üretim endeksi, tüketici fiyat endeksi, döviz kuru, faiz oranı ve para arzının sektörlerin işletme sermayesi unsurlarını (cari aktifler/aktif toplamı, alacak devir hızı, stok devir hızı, nakit dönüşüm süresi ve cari oran) hangi düzeyde etkilediği 20032013 dönemi için panel veri yöntemleriyle (panel birim kök, panel eşbütünleşme ve uzun dönem katsayı tahmini) analiz edilmiştir. Elde edilen bulgular, makroekonomik göstergeler ile kurgulanan modellerden nakit dönüşüm modeli hariç diğer modellerde uzun dönem eşbütünleşme ilişkisinin olduğunu göstermektedir. Bu bulgular, makroekonomik göstergelerin işletme sermayesi düzeyini etkilediğini göstermektedir.

Anahtar Kelimeler: İşletme sermayesi, işletme sermayesi yönetimi, makroekonomik göstergeler, panel veri analizi, eşbütünleşme

\author{
Macroeconomic Determinants of Working \\ Capital: A Comparison between Industries in \\ Borsa Istanbul (BIST)
}

\section{Abstract}

This paper aims to analyze the effects of macroeconomic indicators on working capitals of main metal commodities, food, chemistry, textile, and technology sectors and make a comparison between those sectors. Within this scope, at what level gross domestic product, industrial production index, consumer price index, exchange rates, interest rate and supply of money affected the working capital elements of sectors (current assets/total assets, accounts receivable turnover, inventory turnover, cash conversion cycle and current ratio) in the 2003-2013 term was analyzed by using the methods of panel data (panel unit root, panel cointegration and estimation of long-term coefficients). Results indicate a relation for long-term cointegration between macroeconomic indicators and the designed models, except the cash conversion cycle model. Our findings show that macroeconomic indicators have an effect on levels of working capital.

Keywords: Working capital, working capital management, macroeconomic indicators, panel data analysis, cointegration

\footnotetext{
1 Bu çalışma, Erciyes Üniversitesi Sosyal Bilimler Enstitüsü Muhasebe-Finansman Bilim Dalında yapılan “Temel Makroekonomik Göstergelerin İşletme Sermayesi Üzerine Etkisinin incelenmesi: BIST'te Sektörler Arası Bir Karşılaştırma" başlıklı doktora tezine dayanmaktadır.
} 


\section{Giriş}

İşletme finansmanı literatürü incelendiğinde daha çok yatırım, sermaye yapısı, kâr payı dağıtımı ve firma değerleme gibi uzun vadeli finansal kararlara odaklanıldığı; işletmenin cari varlıkları ile cari yükümlülüklerini kapsayan işletme sermayesi yönetimine daha az önem verildiği görülmektedir. İşletme sermayesi teriminin kökeni, yük arabasını malla doldurarak satmak için yola çıkan Yankee seyyar satıcılarından gelmektedir. Bu satıcıların kâr elde etmek amacıyla sattıkları ticari mallar "çalışma sermayesi" olarak adlandırılıyordu. Sabit varlıklar olan at ve yük arabası genellikle satıcıya ait olurken; ticari mallar tedarikçilerden taksitle ya da banka kredisiyle alınıyordu. Bu krediler işletme sermayesi kalemi olarak adlandırılmaktaydı ve seyyar satıının yeni bir krediyi ödemeye muktedir olduğunu göstermek amacıyla her bir seyahatten sonra geri ödenmek zorundaydı (Brigham ve Houston, 2007: 513).

Geniş anlamda işletme sermayesi, işletme faaliyetlerinin devam ettirilmesinde kullanılan ve kısa sürede nakde dönüştürülme özelliği bulunan varlıklardır (Çakır ve Küçükkaplan, 2012: 70). İşletme sermayesi yönetimi, toplam varlık yatırımları içerisinde önemli bir paya sahip olan cari varlıklara yapılacak yatırımın seviyesi ve bu yatırımların finansmanı ile ilgili kararları içermektedir (Afza ve Nazir, 2008: 25). Başka bir ifadeyle, işletme sermayesi yönetimi, işletmenin dönen varlıklara yatırım yapmasını ve bu varlıkların bir kısmını kısa vadeli yabancı kaynaklarla finanse etmesini ve dönen varlıkların hangi kısmının uzun vadeli yabancı kaynaklarla ve özsermaye ile finanse edileceğine dair bir politikanın geliştirilmesini içermektedir.

İşletme sermayesi bir işletmenin finansal gücünü gösteren önemli ölçütlerden biridir. İ̧̧letme sermayesi düzeyi ne kadar yüksekse işletmenin likiditesi başka bir ifadeyle güvenlik marjının da o kadar yüksek olduğunu söylemek mümkündür. Likit varlıkları yüksek olan bir işletmenin ödeme gücü de yüksektir. Bu durum işletmenin günlük faaliyetlerini sürdürmede, yükümlülüklerini yerine getirmede sıkıntıya düşmeyeceğini gösterir. Tersi durumda ise işletmenin likidite durumu bozulacaktır. Bununla birlikte ödemelerde güçlükler yaşanacak, kredi verenler ile ilişkiler bozulacak, alacakların tahsil kabiliyeti düşecek ve yetersiz stokla çalışma sorunu yaşanacaktır (Tomak, 2013: 8-9). $\mathrm{Bu}$ açıklamalar doğrultusunda işletme sermayesi yönetimi, vadesi gelen finansal yükümlülükleri yerine getirmek için stokları alacaklara, alacakları nakde dönüştürerek yeterli miktarda nakit sağlamak gibi hayâti derecede önemli bir likidite hedefini gözetmelidir (Kolb and DeMong, 1988: 577). Cari varlıkların etkin bir şekilde yönetilmesi firmanın riskliliğini ve kârlılı̆ını önemli ölçüde etkilediğinden dolayı işletme sermayesi unsurlarına yapılacak yatırımın düzeyinin, varlıklar arasındaki dağıımının ve bu varlıkların finansmanının hangi kaynaklardan ve nasıl sağlanacağının hassas bir şekilde analiz edilmesi gerekmektedir.

İşletmelerin faaliyetlerini sürdürdükleri ekonomide meydana gelen değişimlere duyarsız kalmaları, kendilerini soyutlamaları mümkün değildir. İşletme sermayesi 
düzeyi, sektörlerin yapısı itibariyle her sektörde farklılık göstermekte ve ekonomik değişmelere farklı tepkiler verebilmektedir. Makroekonomik göstergelerdeki değişim sadece ülke ekonomilerini etkilemekle kalmayıp işletmeler ile birlikte tüm ekonomik birimleri de etkilemektedir. Makroekonomik göstergelerde meydana gelen değişimler işletmeleri içinde bulunduğu sektör ve faaliyet alanına göre farklı biçimde ve şiddette etkilemekte olup sektör itibari ile işletmelerin işletme sermayesi unsurlarına yaptıkları yatırımları farklı yönde etkilemektedir. İşletme sermayesinin ve unsurlarını birçok faktörden etkilenmesinden dolayı, işletme sermayesi yönetimi ile ilgili kararlar alınırken özenli davranmalı ve birçok makroekonomik değişken analizlere dahil edilmelidir.

İşletme sermayesi yatırımlarının düzeyi işletmelerin kontrolü dışındaki birçok faktörden etkilenmektedir. Bu faktörler işletmelerin faaliyet gösterdiği sektörün kendine has özellikleri ile ilgili olabileceği gibi bir takım makroekonomik değişimlerle de ilgili olabilmektedir (Kök, Coşkun ve İspir, 2013: 50). Makroekonomik koşulların işletme sermayesi yatırımları üzerindeki etkisinin büyüklüğü, sektörden sektöre değişmekte ve sektörler bu değişimlere farklı büyüklüklerde ve hızlarda tepkiler verebilmektedir. Ekonomik koşullarda meydana gelen değişimler işletmeleri doğrudan ve dolaylı olarak etkilemektedir. Özellikle ekonominin daraldığı dönemlerde, planlanan satışlar ve yatırımlar yapılamaz, alacakların tahsilinde gecikmeler yaşanır ve beraberinde borç ödemelerinde sorunlar yaşanmaya başlanır. Likidite sorunlarının ortaya çıkması durumunda hammadde tedariki ve üretim sürecinde aksaklıklar gibi finansal sorunlar baş gösterecektir. Ekonomide değişen koşullar etkisini öncelikle işletmelerin çalışma sermayesinde göstermekte olup işletme sermayesi unsuru olan likit varlıkların, alacakların, stokların ve cari borçların tutarlarında beklenmedik değişikliklere sebep olmaktadır (Şen, Baştürk ve Oruç, 2009: 138). Ekonomik şartlar, büyüme, faiz oranları, enflasyon, para arzındaki büyüme, para ve maliye politikaları gibi makroekonomik faktörler işletme sermayesi kararlarını ve dolayısıyla varlık ve kaynaklara yapılacak yatırımın seviyesini etkilemektedir.

İşletme sermayesi literatürü incelendiğinde, özellikle işletme sermayesi unsurları ile kârlılık arasındaki ilişkiyi araştıran çok sayıda çalışma olduğu görülmektedir. Ancak, ulaşabildiğimiz kadarıyla işletme sermayesinin belirleyicileri üzerine yapılan çalışma sayısının oldukça sınırlı olması, bu çalışma için önemli bir motivasyon kaynağı olmuştur. Literatürdeki, bu önemli boşluğu doldurmak üzere, makroekonomik göstergelerin işletme sermayesi unsurları üzerindeki etkisi, aralarında metal sektörünün de olduğu beş farklı sektör için belirlenmeye çalışıımıştır.

Çalışmanın amacı, temel makroekonomik göstergelerin metal ana sanayi, gıda ve içecek, kimya-kauçuk ve plastik ürünler, tekstil ürünleri, teknoloji-bilişim ve savunma sektörlerinin işletme sermayesi üzerindeki etkisini analiz etmek ve sektörler arasında bir karşılaştırma yapmaktır. Bu çerçevede öncelikle işletme sermayesi yönetimi ve makroekonomik değişkenlerle ilgili literatür incelenmiştir. Daha sonra, BiST'teki beş 
sektörün 2003-2013 dönemi çeyrek dönemlik verilerinden oluşturulan işletme sermayesi unsurları üzerinde makroekonomik göstergelerin uzun dönem etkileri incelenmiştir. Daha özelde ise gayrisafi yurtiçi hâsıla, sanayi üretim endeksi, tüketici fiyat endeksi, döviz kuru, faiz oranı ve para arzının sektörlerin işletme sermayesi unsurlarını hangi düzeyde etkilediği 2003-2013 dönemi için panel veri yöntemleriyle (panel birim kök, panel eşbütünleşme ve uzun dönem katsayı tahmini) analiz edilmiştir.

\section{Literatür İncelemesi}

Finans literatüründe işletme sermayesi üzerine yapılan çalışmalar incelendiğinde bu çalışmaların büyük çoğunluğunun, işletme sermayesi yönetimi ile firma performansı arasındaki ilişki ve işletme sermayesi gereksinimleri ve belirleyicileri üzerinde yoğunlaştığı göze çarpmaktadır. İşletme sermayesi üzerine literatürde yapılan çalışmalarda makroekonomik faktörlerin işletme sermayesi düzeylerine etkileri ile ilgili farklı sonuçlar elde edilmiştir. Çünkü makroekonomik koşulların işletme sermayesi yatırımları üzerindeki etkisinin büyüklüğü ülkeden ülkeye, sektörden sektöre değişmekte ve sektörler bu değişimlere farklı büyüklüklerde ve hızlarda tepkiler vermektedir. Bu bağlamda literatürdeki farklı sonuçları daha net bir şekilde ortaya koyabilmek için yapılan çalışmalar, gelişmiş ve gelişmekte olan ülke ekonomilerine yönelik çalışmalar ile Türkiye üzerine yapılan çalışmalar şeklinde incelenmiş ve çalışmaların özet bilgileri sırasıyla Tablo 1, Tablo 2 ve Tablo 3'te gösterilmiştir.

Tablo 1: Gelişmiş Ülke Ekonomilerine Yönelik Literatür Özeti

\begin{tabular}{|c|c|c|c|c|}
\hline Yazar(lar) & Veri Seti & Metodoloji & Açıklayıcı Değişkenler & Bulgular \\
\hline $\begin{array}{l}\text { Fazzari ve } \\
\text { Petersen } \\
(1993)\end{array}$ & $\begin{array}{l}\text { ABD İmalat } \\
\text { Sektörü } \\
\text { Firmaları, } \\
\text { 1970-1979 }\end{array}$ & Regresyon & $\begin{array}{l}\text { Sabit Yatırım, } \\
\text { Işletme Sermayesi } \\
\text { Değişimi, Toplam } \\
\text { Yatırımlar, Yatırım ve } \\
\text { Nakit Akışları. }\end{array}$ & $\begin{array}{c}\text { İşletme sermayesi } \\
\text { yatırımlarının, nakit akışı } \\
\text { dalgalanmalarına karşı aşırı } \\
\text { duyarlı olduğu; işletme } \\
\text { sermayesinin, bir fon kaynağı ve } \\
\text { kullanımı olarak sabit } \\
\text { yatırımlara dâhil edildiği zaman } \\
\text { negatif bir katsayıya ve nakit } \\
\text { akışları ile yatııımlar arasında } \\
\text { pozitif korelasyona sahip olduğu } \\
\text { tespit edilmiştir. }\end{array}$ \\
\hline $\begin{array}{l}\text { Jose, } \\
\text { Lancaster } \\
\text { ve Stevens } \\
\text { (1996) }\end{array}$ & $\begin{array}{l}\text { Compustat } \\
\text { Verileri, } \\
7 \text { Farklı } \\
\text { Sektörden } \\
2.718 \text { Firma, } \\
1974-1993\end{array}$ & $\begin{array}{l}\text { Çoklu } \\
\text { Regresyon, } \\
\text { Parametrik } \\
\text { Olmayan } \\
\text { Testler }\end{array}$ & $\begin{array}{l}\text { Nakit Dönüşüm Süresi } \\
\text { (CCC), Aktif Kârlılı̆ı (ROA), } \\
\text { Özsermaye Karlıı̆̆ (ROE). }\end{array}$ & $\begin{array}{c}\text { Bütün sektörler için nakit } \\
\text { dönüşüm süresi ile ROA } \\
\text { arasında istatistiki olarak } \\
\text { anlamlı ve negatif bir ilişkinin } \\
\text { varlığı ile ROA yerine ROE } \\
\text { kullanıldığında da korelasyonun } \\
\text { çok farklı olmadığı tespit } \\
\text { edilmiştir. }\end{array}$ \\
\hline
\end{tabular}




\begin{tabular}{|c|c|c|c|c|}
\hline $\begin{array}{l}\text { Wu ve Ho } \\
\text { (1997) }\end{array}$ & $\begin{array}{c}105 \\
\text { Amerikan } \\
\text { Firması, } \\
\text { 1973-1992 }\end{array}$ & $\begin{array}{c}\text { Zaman } \\
\text { Serisi ve } \\
\text { Yatay Kesit } \\
\text { Regresyonu }\end{array}$ & $\begin{array}{c}\text { Cari Oran, Likidite Oranı, } \\
\text { Özkaynak/Toplam Borç, } \\
\text { Stok ve Aktif Devir Hızı, } \\
\text { ROA }\end{array}$ & $\begin{array}{c}\text { Finansal oranların hem dışsal } \\
\text { şoklardan hem de yöneticilerin } \\
\text { bu oranları, belirledikleri hedef } \\
\text { oranlara yaklaştırma } \\
\text { girişimlerinden önemli ölçüde } \\
\text { etkilendiği bulgusuna } \\
\text { ulaşılmışır. }\end{array}$ \\
\hline $\begin{array}{l}\text { Shin ve } \\
\text { Soenen } \\
(1998)\end{array}$ & $\begin{array}{l}\text { Amerikan } \\
\text { Firmaları, } \\
58.985 \\
\text { Gözlem, } \\
\text { 1975-1994 }\end{array}$ & Regresyon & $\begin{array}{l}\text { Net Ticari Dönüş Süresi, } \\
\text { (Faaliyet Kârı + } \\
\text { Amortismanlar)/Toplam } \\
\text { Aktif Oranı, } \\
\text { (Faaliyet Kârı + } \\
\text { Amortismanlar)/Net } \\
\text { Satışlar Oranı, } \\
\text { Cari Oran, } \\
\text { Borç Oranı, } \\
\text { Satışlardaki Büyüme. }\end{array}$ & $\begin{array}{l}\text { Net ticari dönüş süresi ile firma } \\
\text { kârlılığı arasında güçlü negatif } \\
\text { bir ilişki; net ticari dönüş süresi } \\
\text { (\%1 anlam düzeyinde) kısa olan } \\
\text { firmaların daha kârlı olduğu ve } \\
\text { toplam risk birimi başına daha } \\
\text { yüksek risk ayarlı hisse getirisine } \\
\text { sahip oldukları; firmaların hisse } \\
\text { senedi getirileri de net ticari } \\
\text { dönüş süresinin uzunluğu ile } \\
\text { anlamlı düzeyde negatif ilişkili } \\
\text { oldukları tespit edilmiştir. }\end{array}$ \\
\hline $\begin{array}{l}\text { Weinraub } \\
\text { ve } \\
\text { Visscher } \\
\text { (1998) }\end{array}$ & $\begin{array}{l}10 \text { Farklı } \\
\text { Sektörden } \\
216 \\
\text { Amerikan } \\
\text { Firması, } \\
\text { 1984-1993 }\end{array}$ & & $\begin{array}{l}\text { Atılgan ve ihtiyatlı İsletme } \\
\text { Sermayesi Politikaları, } \\
\text { Kısa Vadeli } \\
\text { Yükümlülükler, } \\
\text { Dönen Varlıklar, } \\
\text { Toplam Varlıklar. }\end{array}$ & $\begin{array}{c}\text { Atılgan varlık yönetimi açısından } \\
\text { endüstrilerin kendine özgü ve } \\
\text { önemli ölçüde farklı politikalar } \\
\text { uyguladıkları ve bu politikalarla } \\
\text { ilgili özellikle son } 10 \text { yılda } \\
\text { belirgin bir istikrarın olduğu } \\
\text { tespit edilmiştir. }\end{array}$ \\
\hline $\begin{array}{l}\text { Deloof } \\
(2003)\end{array}$ & $\begin{array}{l}\text { Belçika } \\
\text { Firmaları, } \\
\text { 1009 Firma, } \\
\text { 1992-1996 }\end{array}$ & Regresyon & $\begin{array}{c}\text { ROA, } \\
\text { Alacakların Tahsil Süresi, } \\
\text { Stok Tutma Süresi, } \\
\text { Nakit Dönüşüm Süresi }\end{array}$ & $\begin{array}{l}\text { Firma kârlılığı ile alacak tahsil } \\
\text { süresi, stok tutma süresi ve } \\
\text { borçları erteleme arasında } \\
\text { anlamlı negatif bir ilişkinin } \\
\text { varlığı tespit edilmiştir. }\end{array}$ \\
\hline $\begin{array}{l}\text { Gill, Biger } \\
\text { ve Mathur } \\
\text { (2010) }\end{array}$ & $\begin{array}{l}\text { New York } \\
\text { Borsası'na } \\
\text { Kayıtlı } 88 \\
\text { Imalat } \\
\text { Firması, } 264 \\
\text { Gözlem, } \\
\text { 2005-2007 }\end{array}$ & $\begin{array}{l}\text { Panel Veri } \\
\text { ve } \\
\text { Regresyon }\end{array}$ & $\begin{array}{l}\text { Nakde Dönüşüm Süresi, } \\
\text { Firma Boyutu, } \\
\text { Kaldıraç Oranı, } \\
\text { Duran Varlık / Toplam } \\
\text { Aktifler. }\end{array}$ & $\begin{array}{c}\text { Firma kârlılı̆̆ı ile alacak tahsil } \\
\text { süresi arasında negatif ilişki } \\
\text { tespit edilmiş, firma kârlıı̆ı ile } \\
\text { stok tutma süresi arasında ise } \\
\text { istatistiksel olarak anlamlı bir } \\
\text { ilişki saptanmamıştır. Nakit } \\
\text { dönüşüm süresi ile brüt faaliyet } \\
\text { kârı arasında pozitif ilişki tespit } \\
\text { edilmiştir. }\end{array}$ \\
\hline
\end{tabular}




\begin{tabular}{|c|c|c|c|c|}
\hline $\begin{array}{l}\text { Hill, Kelly } \\
\text { ve } \\
\text { Highfield } \\
\text { (2010) }\end{array}$ & $\begin{array}{c}3.343 \\
\text { Amerikan } \\
\text { Firması, } \\
20.710 \\
\text { Gözlem, } \\
\text { 1996-2006 }\end{array}$ & $\begin{array}{l}\text { Regresyon } \\
\text { (Panel Veri) }\end{array}$ & $\begin{array}{l}\text { Satışlardaki Büyüme, } \\
\text { Brüt Kâr Marjı, } \\
\text { Satışların Değişkenliği, } \\
\text { Faaliyetlerden Nakit } \\
\text { Akışları, PD/DD Oranı, } \\
\text { Firma Büyüklüğü, Pazar } \\
\text { Payı, Mali Sıkıntı. }\end{array}$ & $\begin{array}{l}\text { İşletme sermayesi gereksinimi } \\
\text { ile faaliyetlerden nakit akışları } \\
\text { arasında pozitif ilişski tespit } \\
\text { edilirken, mali sıkıntı ve piyasa } \\
\text { değeri defter değeri oranı } \\
\text { arasında negatif ilişki tespit } \\
\text { edilmiştir. Brüt kâr marjı, pazar } \\
\text { payı ve işletme sermayesi } \\
\text { gereksinimi arasında istatistiksel } \\
\text { olarak anlamlı bir ilişsinin } \\
\text { olmadığı sonucuna ulaşıımıştır. }\end{array}$ \\
\hline $\begin{array}{l}\text { Gill } \\
(2011)\end{array}$ & $\begin{array}{c}\text { Toronto } \\
\text { Borsası'nda } \\
\text { İşlem Gören } \\
166 \text { Kanada } \\
\text { Firması, } \\
2008-2010\end{array}$ & $\begin{array}{l}\text { Panel Veri } \\
\text { Analizi ve } \\
\text { Regresyon }\end{array}$ & $\begin{array}{l}\text { Faaliyet Döngüsü, } \\
\text { Firma Büyümesi, } \\
\text { ROA, Tobin Q, } \\
\text { Kaldıraç Oranı, } \\
\text { Firma Boyutu, } \\
\text { Uluslararasılaşma } \\
\text { Derecesi. }\end{array}$ & $\begin{array}{l}\text { İmalat sektöründe işletme } \\
\text { sermayesi gereksinimini faaliyet } \\
\text { döngüsü, aktif kârlıı̆ı, firmanın } \\
\text { uluslararasılaşma düzeyi ve } \\
\text { işletme ölçeği etkilemektedir. } \\
\text { İşletme sermayesi gereksinimi } \\
\text { ile faaliyetlerden nakit akışları, } \\
\text { Tobin } Q \text {, kaldıraç ve } \\
\text { uluslararasılaşma derecesi } \\
\text { arasında istatistiksel olarak } \\
\text { anlamlı bir ilişkinin olmadığı } \\
\text { sonucuna ulaşılmıştır. }\end{array}$ \\
\hline
\end{tabular}

Gelişmekte olan ülke ekonomileri üzerine yapılan başlıca çalışmalar ve bu çalışmaların ulaştıkları sonuçlar ise Tablo 2'de özetlenmiştir.

Tablo 2: Gelişmekte Olan Ülke Ekonomilerine Yönelik Literatür Özeti

\begin{tabular}{|c|c|c|c|c|}
\hline Yazar(lar) & Veri Seti & Metodoloji & $\begin{array}{l}\text { Açıklayıcı } \\
\text { Değişkenler }\end{array}$ & Bulgular \\
\hline $\begin{array}{l}\text { Eljelly } \\
(2004)\end{array}$ & $\begin{array}{c}\text { Suudi } \\
\text { Arabistan } \\
\text { Firmaları, } \\
\text { 1996-2000 }\end{array}$ & Regresyon & $\begin{array}{c}\text { Net Satışlar, } \\
\text { Toplam Varlıklar, } \\
\text { Nakit Dönüşüm } \\
\text { Süresi, } \\
\text { Cari Oran, } \\
\text { (Faaliyet Kârı + } \\
\text { Amortismanlar)/Net } \\
\text { Satışlar }\end{array}$ & $\begin{array}{l}\text { Firma kârlılığı ve likiditesi } \\
\text { arasında negatif bir ilişki, } \\
\text { endüstri düzeyinde firma } \\
\text { büyüklüğünün kârlıık } \\
\text { üzerinde etkisinin olduğu } \\
\text { ve nakit dönüšüm } \\
\text { süresinin kârlıık } \\
\text { üzerindeki etkisinin cari } \\
\text { oranın kârlılık üzerindeki } \\
\text { etkisine kıyasla daha fazla } \\
\text { olduğu tespit edilmiştir. }\end{array}$ \\
\hline
\end{tabular}




\begin{tabular}{|c|c|c|c|c|}
\hline $\begin{array}{l}\text { Chiou, Cheng } \\
\text { ve Wu (2006) }\end{array}$ & $\begin{array}{c}\text { Tayvan } \\
\text { Firmaları, } \\
19.180 \\
\text { Gözlem, } \\
\text { 1996-2004 }\end{array}$ & Regresyon & $\begin{array}{l}\text { Net Likit Dengesi, } \\
\text { İşletme Sermayesi } \\
\text { Gereksinimi, } \\
\text { Borç Oranı, } \\
\text { Firma Boyutu, } \\
\text { Firma Yaşı, } \\
\text { Aktif Kârlılığı, } \\
\text { Faaliyetlerden Nakit } \\
\text { Akışı, Konjonktürel } \\
\text { Durum. }\end{array}$ & $\begin{array}{l}\text { Net likit dengesi ile borç } \\
\text { oranı arasında negatif; } \\
\text { faaliyetlerden olan nakit } \\
\text { akışları, firma boyutu ve } \\
\text { varlıkların kazanma gücü } \\
\text { arasında pozitif bir } \\
\text { ilişkinin varlığı tespit } \\
\text { edilmiştir. } \\
\text { Işletme sermayesi } \\
\text { yönetimi üzerinde, } \\
\text { endüstri etkisinin, } \\
\text { konjonktür hareketlerin } \\
\text { firma büyümesinin, } \\
\text { performansının ve } \\
\text { boyutunun yeterli } \\
\text { düzeyde etkilediğine dair } \\
\text { kanıtların olmadığı } \\
\text { belirtilmiştir. }\end{array}$ \\
\hline $\begin{array}{l}\text { Lazaridis ve } \\
\text { Tryfonidis } \\
\text { (2006) }\end{array}$ & $\begin{array}{l}\text { Atina Borsası, } \\
131 \text { Firma, } \\
524 \text { Gözlem, } \\
2001-2004\end{array}$ & Regresyon & $\begin{array}{c}\text { Aktif Kârlıı̆̆ı, } \\
\text { Alacakların Tahsil } \\
\text { Süresi, Stok Tutma } \\
\text { Süresi, } \\
\text { Borçların Vadesi, } \\
\text { Kaldıraç Oranı. }\end{array}$ & $\begin{array}{l}\text { Firma kârlılığı ile alacak } \\
\text { tahsil süresi, stok tutma } \\
\text { süresi ve borçların } \\
\text { ödenme süresi arasındaki } \\
\text { ilişki negatiftir. } \\
\text { Nakde dönüşüm } \\
\text { süresinin uzaması karlılığı } \\
\text { olumsuz yönde } \\
\text { etkilemiştir. }\end{array}$ \\
\hline $\begin{array}{l}\text { Padachi } \\
\text { (2006) }\end{array}$ & $\begin{array}{l}58 \text { Küçük } \\
\text { Ölçekli } \\
\text { Moritanya } \\
\text { Firması, } \\
\text { 1998-2003 }\end{array}$ & $\begin{array}{l}\text { Panel Veri } \\
\text { Analizi ve } \\
\text { Regresyon }\end{array}$ & $\begin{array}{c}\text { ROA, } \\
\text { Nakit Dönüşüm } \\
\text { Süresi, Firma Boyutu, } \\
\text { Kaldıraç Oranı, } \\
\text { Brüt İşletme } \\
\text { Sermayesi Devir Hızı, } \\
\text { Dönen Varlık/Toplam } \\
\text { Aktifler. }\end{array}$ & $\begin{array}{l}\text { Alacaklara ve stoklara } \\
\text { yüksek oranda yatırımın } \\
\text { işletmelerde kârlıı̆̆ı } \\
\text { azalttığı ve nakit } \\
\text { dönüşüm süresinin } \\
\text { uzaması ile işletme } \\
\text { kârlılı̆ının azaldığı tespit } \\
\text { edilmiştir. }\end{array}$ \\
\hline $\begin{array}{l}\text { Raheman ve } \\
\text { Nasr } \\
(2007)\end{array}$ & $\begin{array}{l}\text { Karachi Menkul } \\
\text { Kıymetler } \\
\text { Borsası, } \\
94 \text { Pakistan } \\
\text { Firması, } \\
\text { 1999-2004 }\end{array}$ & $\begin{array}{c}\text { Pearson } \\
\text { Korelasyonu, } \\
\text { Regresyon }\end{array}$ & $\begin{array}{l}\text { Net Faaliyet Kâr } \\
\text { Marjı, } \\
\text { Nakde Dönüşüm } \\
\text { Süresi, } \\
\text { Firma Boyutu, } \\
\text { Kaldıraç Oranı, }\end{array}$ & $\begin{array}{l}\text { Alacak tahsil süresi, stok } \\
\text { tutma süresi, borçların } \\
\text { ödenme süresi, nakit } \\
\text { dönüşüm süresi, cari } \\
\text { oran ile firma kârlılığı } \\
\text { arasında güçlü negatif } \\
\text { ilişki saptanmıştır. Kârlılık } \\
\text { ile likidite arasında } \\
\text { anlamlı negatif ilişki; }\end{array}$ \\
\hline
\end{tabular}




\begin{tabular}{|c|c|c|c|c|}
\hline & & & $\begin{array}{c}\text { Finansal } \\
\text { Varlıklar/Toplam } \\
\text { Varlıklar Oranı }\end{array}$ & $\begin{array}{l}\text { firma boyutuyla ise } \\
\text { pozitif ilişki tespit } \\
\text { edilmiştir. }\end{array}$ \\
\hline $\begin{array}{l}\text { Teruel ve } \\
\text { Solano } \\
(2007)\end{array}$ & $\begin{array}{l}\text { İspanya } \\
\text { Borsası, } \\
8.872 \text { Firma, } \\
\text { 1996- } 2002\end{array}$ & $\begin{array}{l}\text { Panel Veri } \\
\text { Analizi ve } \\
\text { Regresyon }\end{array}$ & $\begin{array}{c}\text { ROA, } \\
\text { Alacakların Tahsil } \\
\text { Süresi, } \\
\text { Stok Devir Süresi, } \\
\text { Borçların Ortalama } \\
\text { Vadesi, } \\
\text { Büyüklük, } \\
\text { Satışların Büyümesi, } \\
\text { Kaldıraç Oranı. }\end{array}$ & $\begin{array}{l}\text { İşletme sermayesi } \\
\text { yönetimi ile aktif kârlııı̆ı } \\
\text { ile ölçülen kârlılık } \\
\text { arasında negatif bir ilişki } \\
\text { belirlenmiştir. Firma } \\
\text { kârlılığı ile alacak tahsil } \\
\text { süresi ve stok tutma } \\
\text { süresi arasında negatif } \\
\text { ilişsi vardır. }\end{array}$ \\
\hline $\begin{array}{l}\text { Afza ve } \\
\text { Nazir } \\
(2008)\end{array}$ & $\begin{array}{l}\text { Karachi Menkul } \\
\text { Kıymetler } \\
\text { Borsası, } 17 \\
\text { Farklı Sektör, } \\
263 \text { Firma, } \\
\text { 1998-2003 }\end{array}$ & $\begin{array}{c}\text { Regresyon } \\
\text { (En Küçük } \\
\text { Kareler) }\end{array}$ & $\begin{array}{l}\text { ROA, ROE, Dönen } \\
\text { Varlık/Aktif Toplamı, } \\
\text { KVYK/Aktif Toplamı. }\end{array}$ & $\begin{array}{l}\text { Finansman politikaları ve } \\
\text { işletme sermayesi } \\
\text { yatırımlarının atılganlık } \\
\text { derecesi ile firma kârlılığ } \\
\text { arasında negatif, } \\
\text { finansman politikaları ve } \\
\text { varlık yönetimi } \\
\text { politikaları arasında } \\
\text { negatif bir ilişki tespit } \\
\text { edilmiştir. }\end{array}$ \\
\hline $\begin{array}{c}\text { Ramachandran } \\
\text { ve Janakiraman } \\
\text { (2009) }\end{array}$ & $\begin{array}{l}\text { Hindistan } \\
\text { Kâğıt Sektörü, } \\
\text { 37 Firma, } \\
\text { 1997-2006 }\end{array}$ & Regresyon & $\begin{array}{l}\text { İşletme Sermayesi } \\
\text { Etkinliği, } \\
\text { Faiz ve Vergi Öncesi } \\
\text { Kar (FVÖK), } \\
\text { Nakit Dönüşüm } \\
\text { Süresi. }\end{array}$ & $\begin{array}{l}\text { FVÖK ile nakit dönüşüm } \\
\text { süresi ve borçların } \\
\text { ödenme süresi arasında } \\
\text { negatif yönlü bir ilişki } \\
\text { bulunmuştur. }\end{array}$ \\
\hline $\begin{array}{l}\text { Nazir ve Afza } \\
\quad(2009)\end{array}$ & $\begin{array}{l}\text { Karachi Menkul } \\
\text { Kıymetler } \\
\text { Borsası, } \\
132 \text { imalat } \\
\text { firması }\end{array}$ & $\begin{array}{l}\text { Panel Veri } \\
\text { Analizi ve } \\
\text { Regresyon }\end{array}$ & $\begin{array}{c}\text { ROA, } \\
\text { Dönen Varlık/Aktif } \\
\text { Toplamı, } \\
\text { KVYK/Aktif Toplamı, } \\
\text { Firma Boyutu, } \\
\text { Kaldıraç Oranı, } \\
\text { Tobin Q, } \\
\text { Reel GSYH Büyüme } \\
\text { Oranı. }\end{array}$ & $\begin{array}{l}\text { İşletme sermayesi } \\
\text { gereksinimi ile faaliyet } \\
\text { döngüsü, Tobin Q, ROA, } \\
\text { faaliyetlerden nakit } \\
\text { akışları, reel GSYH } \\
\text { büyüme oranı, satışların } \\
\text { büyümesi ve firma } \\
\text { boyutu arasında pozitif } \\
\text { yönlü ilişki tespit } \\
\text { edilmiştir. } \\
\text { Ayrıca firma kaldıracı ile } \\
\text { işletme sermayesi } \\
\text { gereksinimi arasında } \\
\text { güçlü ve negatif bir } \\
\text { ilişkinin varlığı } \\
\text { bulunmuştur. }\end{array}$ \\
\hline
\end{tabular}




\begin{tabular}{|c|c|c|c|c|}
\hline $\begin{array}{l}\text { Cabellero, } \\
\text { Teruel ve } \\
\text { Solano } \\
\text { (2010) }\end{array}$ & $\begin{array}{c}\text { İspanya } \\
\text { Firmaları, } \\
\text { 4.076 Firma, } \\
\text { 2001-2005 }\end{array}$ & $\begin{array}{c}\text { Sabit Etkiler } \\
\text { Modeli, } \\
\text { Regresyon }\end{array}$ & $\begin{array}{c}\text { Nakde Dönüşüm } \\
\text { Süresi, } \\
\text { Nakit Akışları, } \\
\text { Kaldıraç Oranı, } \\
\text { Firma Boyutu, } \\
\text { Firma Yaşı, } \\
\text { Firma Büyümesi, } \\
\text { Duran Varlık Yatırımı, } \\
\text { ROA. }\end{array}$ & $\begin{array}{l}\text { Uzun nakit dönüşüm } \\
\text { sürecine sahip firmalar, } \\
\text { daha fazla nakit akışı olan } \\
\text { büyük firmalardır. Ayrıca } \\
\text { nakit dönüşüm süreci ile } \\
\text { borç oranı, firma } \\
\text { büyümesi, maddi duran } \\
\text { varlık yatırımları arasında } \\
\text { pozitif bir ilişki tespit } \\
\text { edilirken; varlıkların } \\
\text { kazanma gücü ile negatif } \\
\text { bir ilişki tespit edilmiştir. } \\
\text { GSYH'nın nakit dönüşüm } \\
\text { süresi üzerinde etkisi } \\
\text { olduğuna dair kanıt } \\
\text { bulunamamıştır. }\end{array}$ \\
\hline $\begin{array}{c}\text { Mathuva } \\
\text { (2010) }\end{array}$ & $\begin{array}{l}\text { Nairobi Menkul } \\
\text { Kıymetler } \\
\text { Borsası'na } \\
\text { Kayıtlı } 30 \\
\text { Firma, } \\
468 \text { Gözlem, } \\
\text { 1993-2008 }\end{array}$ & $\begin{array}{c}\text { Sabit Etkiler } \\
\text { Modeli, } \\
\text { Regresyon }\end{array}$ & $\begin{array}{l}\text { Net Faaliyet Kâr } \\
\text { Marjı, Nakde } \\
\text { Dönüşüm Süresi, } \\
\text { Firma Boyutu, } \\
\text { Kaldıraç Oranı, } \\
\text { Maddi Duran } \\
\text { Varlıklar/ Toplam } \\
\text { Varlıklar Oranı ve } \\
\text { GSYH Oranı }\end{array}$ & $\begin{array}{l}\text { Alacak tahsil süresi ile } \\
\text { kârlılık arasında önemli } \\
\text { düzeyde negatif ilişki, } \\
\text { stok bulundurma süresi } \\
\text { ve borç ödeme süresi ile } \\
\text { kârlılık arasında ise güçlü } \\
\text { düzeyde pozitif ilişki ve \% } \\
10 \text { anlam düzeyinde } \\
\text { geçerli olan nakit } \\
\text { dönüşüm süresi ile } \\
\text { kârlılık arasındaki negatif } \\
\text { ilişki tespit edilmiştir. }\end{array}$ \\
\hline $\begin{array}{c}\text { Zariyawati, } \\
\text { Taufig, Annuar } \\
\text { vd. } \\
\text { (2010) }\end{array}$ & $\begin{array}{l}\text { Malezya } \\
\text { Borsası'nda } \\
\text { İşlem Gören } \\
\text { 119 Firma, } \\
\text { 2000-2006 }\end{array}$ & $\begin{array}{c}\text { Sabit Etkiler } \\
\text { Modeli, } \\
\text { Regresyon }\end{array}$ & $\begin{array}{l}\text { Nakde Dönüşüm } \\
\text { Süresi, } \\
\text { Satışların Büyümesi, } \\
\text { Top. Aktifler, } \\
\text { Kaldıraç Oranı, } \\
\text { GSYH, Tüketici Fiyat } \\
\text { Endeksi, Yönetici } \\
\text { Sayısı. }\end{array}$ & $\begin{array}{l}\text { Firma boyutu, kaldıraç } \\
\text { oranı, firma büyümesi, } \\
\text { GSYH ve enflasyon } \\
\text { firmaların işletme } \\
\text { sermayesi düzeyini } \\
\text { etkilemektedir. } \\
\text { GSYH ve enflasyonun } \\
\text { işletme sermayesi } \\
\text { seviyesini önemli ölçüde } \\
\text { etkilediği sonucuna } \\
\text { ulaşılmıştır. }\end{array}$ \\
\hline $\begin{array}{c}\text { Manoori ve } \\
\text { Muhammad } \\
(2012)\end{array}$ & $\begin{array}{l}94 \text { Singapur } \\
\text { Firması, } \\
752 \text { Gözlem, } \\
2003-2010\end{array}$ & $\begin{array}{l}\text { Panel Veri } \\
\text { Analizi ve } \\
\text { Regresyon }\end{array}$ & $\begin{array}{l}\text { Nakde Dönüşüm } \\
\text { Süresi, } \\
\text { Firma Boyutu, } \\
\text { Kaldıraç, } \\
\text { Firma Büyümesi, }\end{array}$ & $\begin{array}{c}\text { Firma boyutu, } \\
\text { faaliyetlerden nakit akışı, } \\
\text { sermaye harcamaları ve } \\
\text { GSYH ile işletme } \\
\text { sermayesi yönetimi } \\
\text { arasında negatif; firma } \\
\text { kârlılığı ile nakit dönüşüm }\end{array}$ \\
\hline
\end{tabular}




\begin{tabular}{|c|c|c|c|c|}
\hline & & & $\begin{array}{l}\text { Nakit Akışları, } \\
\text { Kârlılık, GSYH. }\end{array}$ & $\begin{array}{l}\text { sürecinin uzunluğu } \\
\text { arasında pozitif bir ilişki } \\
\text { tespit edilmiştir. }\end{array}$ \\
\hline $\begin{array}{c}\text { Ukaegbu } \\
\text { (2014) }\end{array}$ & $\begin{array}{c}\text { Mısır, Kenya, } \\
\text { Nijerya ve } \\
\text { Güney Afrika, } \\
\text { İmalat Sektörü } \\
\text { Firmaları, } \\
\text { 2005-2009 }\end{array}$ & $\begin{array}{l}\text { Çoklu } \\
\text { Regresyon, } \\
\text { Chow Testi }\end{array}$ & $\begin{array}{c}\text { Brüt Faaliyet Kârı, } \\
\text { Nakde Dönüşüm } \\
\text { Süresi, GSYH, Firma } \\
\text { Boyutu }\end{array}$ & $\begin{array}{l}\text { Kârlılık ile nakit dönüşüm } \\
\text { ve alacak tahsil süresi } \\
\text { arasında negatif; kârlılık } \\
\text { ile firma boyutu arasında } \\
\text { da pozitif bir ilişki } \\
\text { bulunmuştur. }\end{array}$ \\
\hline
\end{tabular}

Türkiye'de faaliyet gösteren işletmeler üzerine yapılan çalışmalar genellikle Borsa İstanbul'a (BIST) kayıtlı şirketler üzerinden yapılan değerlendirmeler olup sonuçları itibariyle diğer ülkeler üzerine yapılan çalışmalarla benzerlik göstermektedir. Türkiye üzerine yapılan çalışmaların ulaştıkları sonuçlar Tablo 3'te özetlenmiştir.

\section{Tablo 3: Türkiye Ekonomisine Yönelik Literatür Özeti}

\begin{tabular}{|c|c|c|c|c|}
\hline Yazar(lar) & Veri Seti & Metodoloji & $\begin{array}{l}\text { Açılklayıcı } \\
\text { Değişkenler }\end{array}$ & Bulgular \\
\hline $\begin{array}{l}\text { Yücel ve Kurt } \\
\quad(2002)\end{array}$ & $\begin{array}{c}\text { Borsa } \\
\text { İstanbul } \\
\text { (BIST)'da } \\
\text { İşlem Gören } \\
167 \text { Firma, } \\
\text { 1995-2000 }\end{array}$ & Regresyon & $\begin{array}{c}\text { Net Kar Marjı, } \\
\text { Aktif Karlııı̆ı, } \\
\text { Özsermaye Karlııı̆ı, } \\
\text { Nakde Dönüşüm } \\
\text { Süresi, } \\
\text { Cari Oran, } \\
\text { Likidite Oranı, } \\
\text { Kaldıraç Oranı. }\end{array}$ & $\begin{array}{l}\text { Nakit dönüş süresinin likidite } \\
\text { oranları ile pozitif, aktif kârlılığı } \\
\text { ve özsermaye kârlılığı ile negatif } \\
\text { ilişsisi tespit edilmiştir. } \\
\text { Nakit dönüş süresinin dönemsel } \\
\text { olarak farklı olmadığı, buna } \\
\text { karşılık sektörler ve işletme } \\
\text { ölçeğine göre istatistiksel olarak } \\
\text { anlamlı farklılıklar olduğu ortaya } \\
\text { konmuştur. }\end{array}$ \\
\hline $\begin{array}{l}\text { Öz ve } \\
\text { Güngör } \\
\text { (2007) }\end{array}$ & $\begin{array}{l}\text { BIST İmalat } \\
\text { Sektörü, } 68 \\
\text { Firma, } \\
\text { 1992-2005 }\end{array}$ & $\begin{array}{l}\text { Panel Veri } \\
\text { Analizi ve } \\
\text { Regresyon }\end{array}$ & $\begin{array}{c}\text { Brüt Satış Kârı, } \\
\text { Alacakların Tahsil } \\
\text { Süresi, Stok Tutma } \\
\text { Süresi, } \\
\text { Borçların Vadesi, } \\
\text { Net Ticaret Süresi, } \\
\text { Firma Büyüklüğü. }\end{array}$ & $\begin{array}{c}\text { Firma kârlılığı ile çalışma } \\
\text { sermayesi yönetimini temsil } \\
\text { eden alacak devir hızı, borç devir } \\
\text { hızı, stok devir hızı ve net ticaret } \\
\text { süresi arasında negatif, } \\
\text { satışlardaki büyüme ve mali } \\
\text { duran varlıkların toplam aktiflere } \\
\text { oranı arasında pozitif ve anlamlı } \\
\text { bir ilişki tespit edilmiştir. }\end{array}$ \\
\hline
\end{tabular}




\begin{tabular}{|c|c|c|c|c|}
\hline $\begin{array}{l}\text { Öztürk ve } \\
\text { Demirgüneş } \\
\text { (2008) }\end{array}$ & $\begin{array}{l}\text { BIST, } \\
\text { Metal Eşya, } \\
\text { Makine ve } \\
\text { Gereç Yapım } \\
\text { Sektörü, } \\
\text { 2002-2006 }\end{array}$ & Regresyon & $\begin{array}{c}\text { Aktif Karlılığı, } \\
\text { Alacakların Tahsil } \\
\text { Süresi, } \\
\text { Stok Tutma Süresi, } \\
\text { Nakde Dönüşüm } \\
\text { Süresi, } \\
\text { Kaldıraç Oranı, } \\
\text { Satışlardaki Büyüme. }\end{array}$ & $\begin{array}{c}\text { Kaldıraç oranının, aktif } \\
\text { kârlııı̆ının ve büyümenin işletme } \\
\text { sermayesi gereksinimini } \\
\text { istatistiksel olarak anlamlı bir } \\
\text { biçimde etkilediği sonucuna } \\
\text { ulaşılmıştır. }\end{array}$ \\
\hline $\begin{array}{c}\text { Şamiloğlu ve } \\
\text { Demirgüneş } \\
\text { (2008) }\end{array}$ & $\begin{array}{l}\text { BIST İmalat } \\
\text { Sektörü, } \\
5.843 \\
\text { Gözlem, } \\
\text { 1998-2007 }\end{array}$ & $\begin{array}{c}\text { Çoklu } \\
\text { Regresyon }\end{array}$ & $\begin{array}{c}\text { ROA, } \\
\text { Nakde Dönüşüm } \\
\text { Süresi, } \\
\text { Firma Boyutu, } \\
\text { Kaldıraç Oranı, } \\
\text { Maddi Duran } \\
\text { Varlıklar/Aktif } \\
\text { Toplamı. }\end{array}$ & $\begin{array}{l}\text { Nakit dönüşüm döngüsü, firma } \\
\text { boyutu ve maddi duran } \\
\text { varlıklar/toplam varlıklar oranı ile } \\
\text { firma kârlıı̆ı arasında istatistiki } \\
\text { olarak anlamlı bir ilişkinin } \\
\text { olmadığı sonucuna ulaşııııştır. }\end{array}$ \\
\hline $\begin{array}{l}\text { Uyar } \\
\text { (2009) }\end{array}$ & $\begin{array}{c}\text { BIST, } \\
\text { Perakende ve } \\
\text { Imalat } \\
\text { Sektöründe } \\
\text { İşlem Gören } \\
166 \text { Firma, } \\
2007\end{array}$ & $\begin{array}{l}\text { ANOVA ve } \\
\text { Pearson } \\
\text { Korelasyon } \\
\text { Analizi }\end{array}$ & $\begin{array}{l}\text { Nakde Dönüşüm } \\
\text { Süresi, } \\
\text { Aktif Toplamı, } \\
\text { Net Satışlar. }\end{array}$ & $\begin{array}{l}\text { Nakit döngüsü uzunluğunun net } \\
\text { satışlar ve toplam varlıklar } \\
\text { bakımından firma boyutu ile } \\
\text { anlamlılık seviyesinde negatif bir } \\
\text { ilişkiye sahip olduğu ortaya } \\
\text { konmuştur. Nakit döngüsü } \\
\text { uzunluğu ile firma kârlııı̆ı } \\
\text { arasında anlamlı ve negatif bir } \\
\text { korelasyon tespit edilmiştir. }\end{array}$ \\
\hline $\begin{array}{l}\text { Omağ } \\
(2009)\end{array}$ & $\begin{array}{l}\text { ABD ve } \\
\text { Türkiye'de } \\
\text { Gıda } \\
\text { Sektöründe } \\
\text { Faaliyet } \\
\text { Gösteren } \\
\text { KOBi'ler, } \\
\text { 2002-2007 }\end{array}$ & $\begin{array}{l}\text { Durum } \\
\text { Analizi }\end{array}$ & $\begin{array}{l}\text { Nakde Dönüşüm } \\
\text { Süresi, } \\
\text { Satışlar. }\end{array}$ & $\begin{array}{l}\text { Her iki ülkenin sektöründe de } \\
\text { dalgalı bir seyrin olduğu ancak } \\
\text { Türk firmalarının nakit dönüşüm } \\
\text { sürelerinin daha dalgalı bir seyir } \\
\text { izlediği sonucuna ulaşılmıştır. }\end{array}$ \\
\hline $\begin{array}{c}\text { Şen ve Oruç } \\
(2009)\end{array}$ & $\begin{array}{l}\text { BIST İmalat } \\
\text { Sektörü, } \\
49 \text { Firma, } \\
\text { 1993-2007 }\end{array}$ & $\begin{array}{l}\text { Sabit Etkiler } \\
\text { ve Tesadüfü } \\
\text { Etkiler } \\
\text { Modeli, } \\
\text { Regresyon }\end{array}$ & $\begin{array}{c}\text { ROA, } \\
\text { Nakde Dönüşüm } \\
\text { Süresi, } \\
\text { Cari Oran, } \\
\text { Net İşletme } \\
\text { Sermayesi. }\end{array}$ & $\begin{array}{l}\text { Cari oran, net işletme sermayesi } \\
\text { düzeyi, nakit döngüsü, alacak } \\
\text { tahsil süresi, stok bulundurma } \\
\text { süresi ile aktif kârlılı̆ı arasında } \\
\text { negatif bir iliş̧i ortaya } \\
\text { konmuştur. }\end{array}$ \\
\hline
\end{tabular}




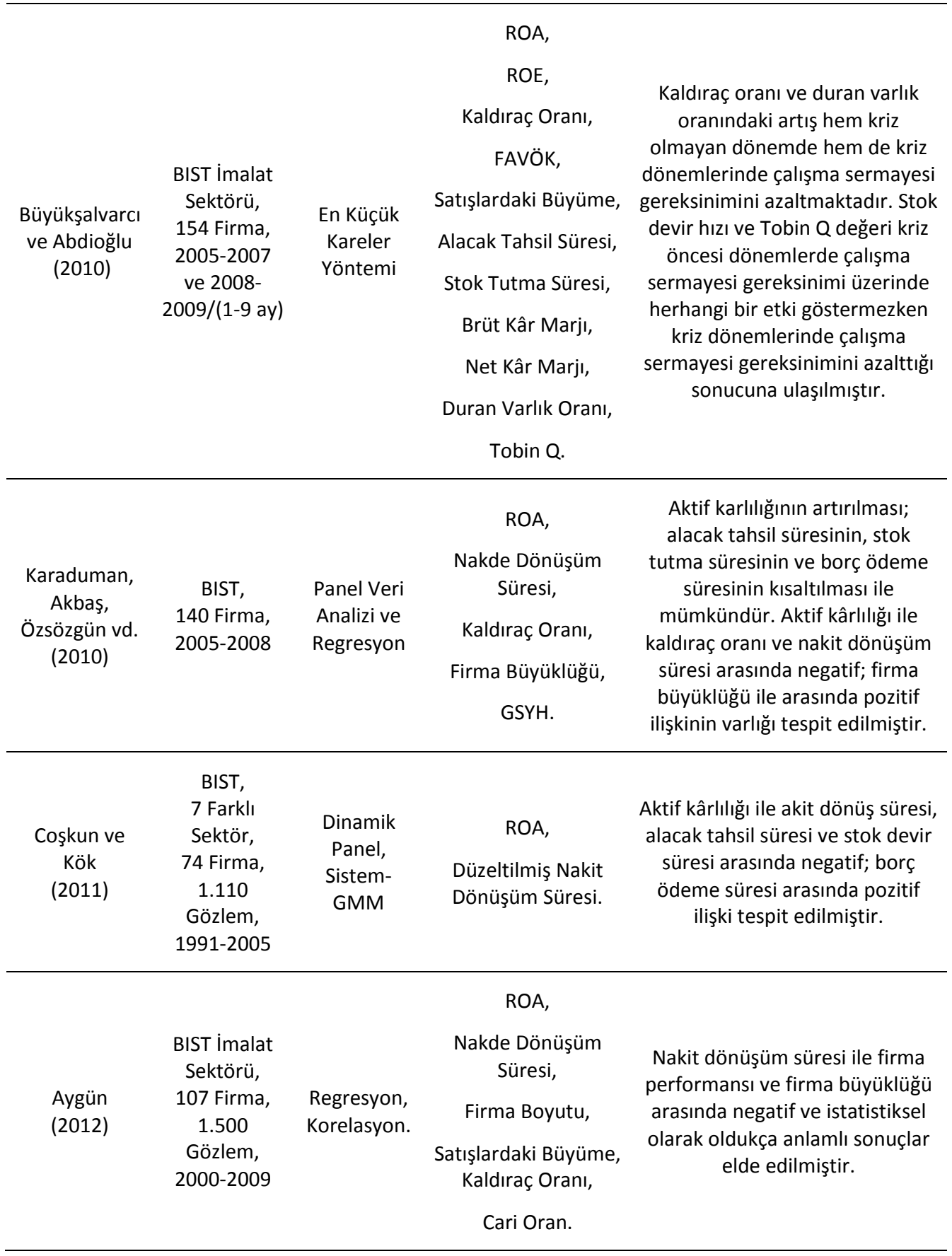




\begin{tabular}{|c|c|c|c|c|}
\hline $\begin{array}{c}\text { Çakır ve } \\
\text { Küçükkaplan } \\
\text { (2012) }\end{array}$ & $\begin{array}{l}\text { BIST İmalat } \\
\text { Sektörü, } \\
122 \text { Firma, } \\
2000-2009\end{array}$ & $\begin{array}{c}\text { Panel Veri } \\
\text { Analizi, } \\
\text { Regresyon }\end{array}$ & $\begin{array}{c}\text { ROA, ROE, } \\
\text { PD/DD, Likidite } \\
\text { Oranları, Alacak } \\
\text { Devir Hızı, Stok Devir } \\
\text { Hızı, Aktif Devir Hızı, } \\
\text { Kısa Vadeli Borç } \\
\text { Oranı. }\end{array}$ & $\begin{array}{l}\text { Cari oran ve kaldıraç oranının } \\
\text { aktif kârııı̆ıgla negatif ilişkili } \\
\text { olduğu, asit test oranı, stok devir } \\
\text { hızı ve aktif devir hızının ise } \\
\text { kârlılığa pozitif ve anlamlı } \\
\text { etkisinin olduğu ortaya } \\
\text { konmuştur. } \\
\text { İşletme sermayesi unsurları ile } \\
\text { özsermaye kârlılığı ve piyasa } \\
\text { değeri arasında anlamlı bir ilişki } \\
\text { tespit edilememiştir. }\end{array}$ \\
\hline $\begin{array}{c}\text { Dursun ve } \\
\text { Ayrıçay } \\
\text { (2012) }\end{array}$ & $\begin{array}{l}\text { BIST } \\
120 \text { Üretim } \\
\text { ve Ticaret } \\
\text { Firması, } \\
1.200 \\
\text { Gözlem, } \\
\text { 1995-2005 }\end{array}$ & $\begin{array}{l}\text { En Küçük } \\
\text { Kareler } \\
\text { ve } \\
\text { Sabit Etkiler } \\
\text { Modeli }\end{array}$ & $\begin{array}{l}\text { Brüt Satış Kârı, } \\
\text { Net Ticaret Süresi, } \\
\text { Firma Büyüklüğü, } \\
\text { Kaldıraç Oranı, } \\
\text { Finansal Duran } \\
\text { Varlık Oranı. }\end{array}$ & $\begin{array}{c}\text { Brüt karlıık ile stok devir süresi, } \\
\text { borç ödeme süresi ve net ticaret } \\
\text { süresi arasında istatistiki açıdan } \\
\text { anlamlı negatif ilişki tespit } \\
\text { edilmiştir. }\end{array}$ \\
\hline $\begin{array}{l}\text { Işı|k ve Kiracı } \\
\text { (2012) }\end{array}$ & $\begin{array}{l}\text { BIST Sınai } \\
\text { Endeksi, } \\
110 \text { Firma, } \\
7.920 \\
\text { Gözlem, } \\
\text { 2005-2010 }\end{array}$ & $\begin{array}{l}\text { Durum } \\
\text { Analizi }\end{array}$ & $\begin{array}{c}\text { Likidite Oranları, } \\
\text { Nakde Dönüşüm } \\
\text { Süresi, Dönen Varlık } \\
\text { Devir Hızı, Kısa } \\
\text { Vadeli Borç/Toplam } \\
\text { Borç Oranı, } \\
\text { Dönen } \\
\text { Varlık/Toplam Varlık } \\
\text { Oranı, } \\
\text { Brüt Kar Marjı, } \\
\text { Net Çalışma } \\
\text { Sermayesi/Dönen } \\
\text { Varlık Oranı. }\end{array}$ & $\begin{array}{l}\text { Kriz öncesi ve kriz sonrası üç yıllık } \\
\text { dönem karşılaştııılmasında, } \\
\text { çalışma sermayesinin yeterliliğini } \\
\text { gösteren likidite oranları } \\
\text { değişmezken, çalışma } \\
\text { sermayesinin verimli } \\
\text { kullanılmasıyla ilgili olan faaliyet } \\
\text { oranlarının azaldığı ve bunun } \\
\text { sonucu olarak brüt kâr } \\
\text { oranlarının azaldığı tespit } \\
\text { edilmiştir. } \\
2007-2008 \text { yılları için likidite ile } \\
\text { faaliyet oranlarının } 2008 \text { yılında } \\
2007 \text { yıına göre düştüğü, brüt } \\
\text { kâr oranının azaldığı sonucu elde } \\
\text { edilmiştir. }\end{array}$ \\
\hline $\begin{array}{l}\text { Vural, } \\
\text { Sökmen ve } \\
\text { Çetenak } \\
\text { (2012) }\end{array}$ & $\begin{array}{l}\text { BIST İmalat } \\
\text { Sektörü, } \\
75 \text { Firma, } \\
600 \text { Gözlem, } \\
\text { 2002-2009 }\end{array}$ & $\begin{array}{c}\text { Dinamik } \\
\text { Panel, } \\
\text { Regresyon }\end{array}$ & $\begin{array}{l}\text { Brüt Faaliyet Kârı, } \\
\text { Nakde Dönüşüm } \\
\text { Süresi, Firma } \\
\text { Boyutu, } \\
\text { Kaldıraç Oranı, } \\
\text { Tobin Q. }\end{array}$ & $\begin{array}{l}\text { Alacak tahsil süresi ve nakit } \\
\text { dönüşüm döngüsü firma kârlılığı } \\
\text { ile negatif ilişkilidir. Firma değeri } \\
\text { ile kaldıraç oranı arasında } \\
\text { negatif; nakit dönüşüm döngüsü } \\
\text { ile firma değeri arasında da } \\
\text { pozitif bir ilişki tespit edilmiştir. }\end{array}$ \\
\hline
\end{tabular}




\begin{tabular}{|c|c|c|c|c|}
\hline $\begin{array}{l}\text { Çakır } \\
\text { (2013) }\end{array}$ & $\begin{array}{l}\text { BIST, İmalat } \\
\text { Sektörü, } \\
52 \text { Firma, } \\
2000-2010\end{array}$ & Regresyon & $\begin{array}{l}\text { FVÖK/Devamlı } \\
\text { Sermaye, } \\
\text { Aktif Devir Hızı, } \\
\text { Nakde Dönüşüm } \\
\text { Süresi, } \\
\text { Kısa Vadeli Borç } \\
\text { Ödeme Süresi. }\end{array}$ & $\begin{array}{l}\text { İmalat sanayi beklenenin aksine } \\
\text { işletmelerin nakit dönüşüm } \\
\text { süresini artırarak kârlılıklarını } \\
\text { artırabilecekleri sonucuna } \\
\text { ulaşılmıştır. Kimya ve taş alt } \\
\text { sektörlerinde ise kârlılık ile nakit } \\
\text { dönüšüm süresi arasında ters } \\
\text { yönlü bir ilişsi bulunmuştur. }\end{array}$ \\
\hline $\begin{array}{l}\text { Kök, Coşkun } \\
\text { ve İspir } \\
(2013)\end{array}$ & $\begin{array}{l}\text { BIST İmalat } \\
\text { Sektörü, } \\
\text { 1990-2009 }\end{array}$ & $\begin{array}{l}\text { Panel Veri } \\
\text { Analizi, KPSS } \\
\text { Testi }\end{array}$ & $\begin{array}{c}\text { Alacak Tahsil Süresi, } \\
\text { Stok Tutma Süresi, } \\
\text { Borçların Ödenme } \\
\text { Süresi, } \\
\text { Nakit Dönüşüm } \\
\text { Süresi. }\end{array}$ & $\begin{array}{l}\text { Sabit ve trendli modelde her bir } \\
\text { alt sektör ve örneklemin bütünü } \\
\text { için nakit dönüş süresinin } \\
\text { durağan olduğu sonucu elde } \\
\text { edilmiştir. } \\
\text { Sektörel veya makroekonomik } \\
\text { kaynaklı dalgalanmaların nakit } \\
\text { dönüş süresinde geçici olduğu, } \\
\text { çalışma sermayesinin belirli bir } \\
\text { ortalama etrafına döndüğü ileri } \\
\text { sürülmüştür. }\end{array}$ \\
\hline
\end{tabular}

\section{Model, Veri Seti, Yöntem ve Bulgular}

Aşağıda iki ayrı alt başlıkta araştırmanın veri tabanı, analiz yöntemi ve analiz bulgularına ilişkin bilgilere yer verilmiştir.

\subsection{Model ve Veri Seti}

Bu çalışma, 2003-2013 dönemi Borsa İstanbul'daki 5 sektörü (metal ana sanayi, gıda ve içecek, kimya-kauçuk ve plastik ürünler, tekstil ürünleri, teknoloji-bilişim ve savunma) kapsamaktadır. Sektörlerde yer alan firmalara ilişkin veriler üçer aylık dönemleri kapsamakta olup BiST'in resmi internet sitesinden, Kamuyu Aydınlatma Platformu'ndan (KAP), Finnet Borsa Bilgi Servisi'nden ve firmaların web sayfalarında yayınlanan finansal tablolardan elde edilmiştir. Makroekonomik göstergelerin sektörler üzerindeki uzun dönemli etkisini açık bir şekilde ortaya koyabilmek için 20032013 dönemini kapsayan 11 yıllık bir analiz dönemi belirlenmiştir.

Araştırmanın bağımlı değişkenleri ve işletme sermayesi unsuru olarak; stok devir hızı, alacak devir hızı, nakit dönüşüm süresi, cari oran ve cari varlık/toplam varlık oranı kullanılmıştır. Bağımsız değişkenler ve temel makroekonomik göstergeler olarak, gayrisafi yurtiçi hâsıla, sanayi üretim endeksi, tüketici fiyatları endeksi, döviz kuru, faiz oranı ve para arzı kullanılmıştır. Araştırmanın sektörler bazındaki bağımlı değişkenleri aşağıdaki gibi hesaplanmıştır:

- CAA: Cari Aktifler / Toplam Aktifler Oranı = Dönen Varlık Toplamı/Aktif Toplamı

- ADH: Alacak Devir Hızı = Net Satışlar/Ortalama Ticari Alacaklar 
- SDH: Stok Devir Hızı = Satışların Maliyeti/Ortalama Stoklar

- NDS: Nakde Dönüşüm Süresi = (Stok Tutma Süresi + Alacakların Tahsil Süresi) - Kısa Vadeli Borç Ödeme Süresi

- CO: Cari Oran = Dönen Varlıklar/Kısa Vadeli Yabancı Kaynaklar

Araştırmanın bağımsız değişkenleri ise Türkiye Cumhuriyet Merkez Bankası Elektronik Veri Dağıtım Sistemi ve Türkiye İstatistik Kurumu resmi internet sitesinden üçer aylık dönemler halinde elde edilmiştir. Yukarıda da belirtildiği üzere bağımsız değişkenler olarak; reel gayrisafi yurtiçi hâsıla (GSYH), sanayi üretim endeksi (SAN), tüketici fiyatları endeksi (TÜFE), döviz kuru (KUR), faiz oranı (FAiz) ve para arzı (M2) kullanılmıştır. Bu makroekonomik göstergelerden gayrisafi yurtiçi hâsıla ve sanayi üretim endeksi mevsimsel etkiden arındırılarak analize dahil edilmiştir. Yine döviz kuru olarak reel efektif döviz kuru kullanıımışır. Para arzı olarak M2 para stoku esas alınmıştır. Faiz oranı olarak bankalarca açılan mevduatlara uygulanan ağırlıklı ortalama faiz oranları esas alınmıştır.

Çalışma kapsamında tahmin edilecek modeller aşağıdaki gibi kurgulanmıştır:

Model 1:

$C A A_{i t}=\beta_{0 i}+\beta_{1 i} F A \dot{I Z}_{i t}+\beta_{2 i} T U F E_{i t}+\beta_{3 i} K U R_{i t}+\beta_{4 i} M 2_{i t}+\beta_{5 i} G S Y H_{i t}+\beta_{6 i} S A N_{i t}+\varepsilon_{i t}$

Model 1'de bağımlı değişken Dönen Varlıklar/Aktif Toplamıdır.

Model 2:

$A D H_{i t}=\beta_{0 i}+\beta_{1 i} F A \dot{I} Z_{i t}+\beta_{2 i} T U F E_{i t}+\beta_{3 i} K U R_{i t}+\beta_{4 i} M 2_{i t}+\beta_{5 i} G S Y H_{i t}+\beta_{6 i} S A N_{i t}+\varepsilon_{i t}$ Model 2'de bağımlı değişken alacak devir hızıdır.

Model 3:

$S D H_{i t}=\beta_{0 i}+\beta_{1 i} F A \dot{I} Z_{i t}+\beta_{2 i} T U F E_{i t}+\beta_{3 i} K U R_{i t}+\beta_{4 i} M 2_{i t}+\beta_{5 i} G S Y H_{i t}+\beta_{6 i} S A N_{i t}+\varepsilon_{i t}$ Model 3'te bağımlı değişken stok devir hızıdır.

Model 4:

$N D S_{i t}=\beta_{0 i}+\beta_{1 i} F A \dot{I} Z_{i t}+\beta_{2 i} T U F E_{i t}+\beta_{3 i} K U R_{i t}+\beta_{4 i} M 2_{i t}+\beta_{5 i} G S Y H_{i t}+\beta_{6 i} S A N_{i t}+\varepsilon_{i t}$

Model 4 'te bağımlı değişken nakit veya nakde dönüşüm süresidir.

Model 5:

$C O_{i t}=\beta_{0 i}+\beta_{1 i} F A \dot{I} Z_{i t}+\beta_{2 i} T U F E_{i t}+\beta_{3 i} K U R_{i t}+\beta_{4 i} M 2_{i t}+\beta_{5 i} G S Y H_{i t}+\beta_{6 i} S A N_{i t}+\varepsilon_{i t}$ Model 5 'te ise bağımlı değişken cari orandır.

\subsection{Ampirik Bulgular}

Çalışmada, 2003-2013 döneminde temel makroekonomik göstergelerin belirlenen sektörlerin işletme sermayesi üzerindeki uzun dönem etkileri panel eşbütünleşme yöntemleri ile tahmin edilmiştir. Uzun dönem eşbütünleşme ilişkisinin varlığı tespit 
edildikten sonra her bir sektör için açıklayıcı değişkenlere ait uzun dönem katsayılarının tahmini yapılmıştır.

Ilk olarak bir zaman serisinin ve panel verinin istatistiksel analizine geçmeden önce, o seriyi meydana getiren sürecin zaman içerisinde sabit olup olmadığı başka bir ifadeyle serinin durağan olup olmadığının incelenmesi gerekmektedir.

\subsubsection{Panel Birim Kök Testleri}

Eşbütünleşme analizlerinin yapılmasında panel veri setini oluşturan değişkenlerin birim kök özellikleri önemli bir role sahip olduğu için ilk olarak panel birim kök analizi yapılmıştır. Bu kapsamda çalışmada değişkenler, panel birim kök testlerinden Levin, Lin ve Chu (2002, LLC), Im, Pesaran ve Shin (2003, IPS) ve Maddala ve Wu (1999) tarafından geliştirilen ADF Fisher birim kök sınama yöntemleri ile analiz edilerek serilerin hem düzey hem de birinci farkları için birim kök sonuçları Tablo 4'te verilmiştir.

Tablo 4: Panel Birim Kök Testi Sonuçları

\begin{tabular}{|c|c|c|c|c|c|c|}
\hline \multirow[b]{2}{*}{ Değişken } & \multicolumn{2}{|c|}{ LLC } & \multicolumn{2}{|c|}{ IPS } & \multicolumn{2}{|c|}{ ADF-FISHER } \\
\hline & Sabitli & $\begin{array}{l}\text { Sabitli- } \\
\text { Trendli }\end{array}$ & Sabitli & $\begin{array}{l}\text { Sabitli- } \\
\text { Trendli }\end{array}$ & Sabitli & $\begin{array}{l}\text { Sabitli- } \\
\text { Trendli }\end{array}$ \\
\hline CAA & $\begin{array}{l}0,055 \\
(0,522)\end{array}$ & $\begin{array}{c}1,917 \\
(0,972)\end{array}$ & $\begin{array}{l}-1,173 \\
(0,120)\end{array}$ & $\begin{array}{c}0,100 \\
(0,539)\end{array}$ & $\begin{array}{l}13,792 \\
(0,182)\end{array}$ & $\begin{array}{c}7,906 \\
(0,637)\end{array}$ \\
\hline ADH & $\begin{array}{l}12,639 \\
(1,000)\end{array}$ & $\begin{array}{l}22,931 \\
(1,000)\end{array}$ & $\begin{array}{l}-0,921 \\
(0,178)\end{array}$ & $\begin{array}{l}-1,160 \\
(0,123)\end{array}$ & $\begin{array}{l}13,025 \\
(0,222)\end{array}$ & $\begin{array}{l}12,150 \\
(0,275)\end{array}$ \\
\hline SDH & $\begin{array}{l}9,986 \\
(1,000)\end{array}$ & $\begin{array}{l}18,281 \\
(1,000)\end{array}$ & $\begin{array}{c}-1,907 * * \\
(0,028)\end{array}$ & $\begin{array}{l}-3,029^{*} \\
(0,001)\end{array}$ & $\begin{array}{l}27,791^{*} \\
(0,001)\end{array}$ & $\begin{array}{c}33,596 * \\
(0,000)\end{array}$ \\
\hline co & $\begin{array}{l}-0,229 \\
(0,409)\end{array}$ & $\begin{array}{l}-0,990 \\
(0,160)\end{array}$ & $\begin{array}{c}-1,650^{* *} \\
(0,049)\end{array}$ & $\begin{array}{c}-1,955^{* *} \\
(0,025)\end{array}$ & $\begin{array}{c}20,026^{* *} \\
(0,029)\end{array}$ & $\begin{array}{c}17,261 * * * \\
(0,068)\end{array}$ \\
\hline NDS & $\begin{array}{l}0,206 \\
(0,581)\end{array}$ & $\begin{array}{c}0,776 \\
(0,718)\end{array}$ & $\begin{array}{l}-0,128 \\
(0,448)\end{array}$ & $\begin{array}{c}0,261 \\
(0,603)\end{array}$ & $\begin{array}{c}7,161 \\
(0,710)\end{array}$ & $\begin{array}{c}7,763 \\
(0,651)\end{array}$ \\
\hline FAiz & $\begin{array}{l}-0,053 \\
(0,478)\end{array}$ & $\begin{array}{l}1,583 \\
(0,943)\end{array}$ & $\begin{array}{l}-0,734 \\
(0,231)\end{array}$ & $\begin{array}{c}-2,186^{* *} \\
(0,014)\end{array}$ & $\begin{array}{c}9,495 \\
(0,485)\end{array}$ & $\begin{array}{c}18,218^{* * *} \\
(0,051)\end{array}$ \\
\hline TÜFE & $\begin{array}{l}4,820 \\
(1,000)\end{array}$ & $\begin{array}{l}3,435 \\
(0,999)\end{array}$ & $\begin{array}{c}5,529 \\
(1,000)\end{array}$ & $\begin{array}{c}3,599 \\
(0,999)\end{array}$ & $\begin{array}{c}0,021 \\
(1,000)\end{array}$ & $\begin{array}{c}0,114 \\
(1,000)\end{array}$ \\
\hline KUR & $\begin{array}{l}-3,046^{*} \\
(0,001)\end{array}$ & $\begin{array}{c}1,084 \\
(0,861)\end{array}$ & $\begin{array}{l}-4,500 * \\
(0,000)\end{array}$ & $\begin{array}{c}-1,579 * * * \\
(0,057)\end{array}$ & $\begin{array}{c}38,246^{*} \\
(0,000)\end{array}$ & $\begin{array}{l}15,182 \\
(0,125)\end{array}$ \\
\hline
\end{tabular}




\begin{tabular}{|c|c|c|c|c|c|c|}
\hline M2 & $\begin{array}{c}5,608 \\
(1,000)\end{array}$ & $\begin{array}{c}2,218 \\
(0,986)\end{array}$ & $\begin{array}{c}8,492 \\
(1,000)\end{array}$ & $\begin{array}{c}0,286 \\
(0,612)\end{array}$ & $\begin{array}{c}0,003 \\
(1,000)\end{array}$ & $\begin{array}{c}6,036 \\
(0,812)\end{array}$ \\
\hline GSYH & $\begin{array}{c}-1,529 * * * \\
(0,063)\end{array}$ & $\begin{array}{c}-1,291^{* * *} \\
(0,098)\end{array}$ & $\begin{array}{c}0,989 \\
(0,838)\end{array}$ & $\begin{array}{l}-1,136 \\
(0,127)\end{array}$ & $\begin{array}{c}3,672 \\
(0,960)\end{array}$ & $\begin{array}{l}12,606 \\
(0,246)\end{array}$ \\
\hline SAN & $\begin{array}{c}-1,982^{* *} \\
(0,023)\end{array}$ & $\begin{array}{l}-0,357 \\
(0,360)\end{array}$ & $\begin{array}{c}0,191 \\
(0,424)\end{array}$ & $\begin{array}{l}-0,894 \\
(0,185)\end{array}$ & $\begin{array}{c}7,442 \\
(0,683)\end{array}$ & $\begin{array}{l}11,304 \\
(0,334)\end{array}$ \\
\hline$\triangle \mathrm{CAA}$ & $\begin{array}{c}-13,551^{*} \\
(0,000)\end{array}$ & $\begin{array}{c}-12,813^{*} \\
(0,000)\end{array}$ & $\begin{array}{c}-14,038^{*} \\
(0,000)\end{array}$ & $\begin{array}{c}-13,490 * \\
(0,000)\end{array}$ & $\begin{array}{r}144,466 * \\
(0,000)\end{array}$ & $\begin{array}{c}137,565^{*} \\
(0,000)\end{array}$ \\
\hline$\triangle \mathrm{ADH}$ & $\begin{array}{c}-38,152 * \\
(0,000)\end{array}$ & $\begin{array}{c}-60,035^{*} \\
(0,000)\end{array}$ & $\begin{array}{c}-34,971^{*} \\
(0,000)\end{array}$ & $\begin{array}{c}-56,771^{*} \\
(0,000)\end{array}$ & $\begin{array}{c}78,426^{*} \\
(0,000)\end{array}$ & $\begin{array}{c}812,439 * \\
(0,000)\end{array}$ \\
\hline$\Delta \mathrm{SDH}$ & $\begin{array}{l}-5,659 * \\
(0,000)\end{array}$ & $\begin{array}{c}-13,388^{*} \\
(0,000)\end{array}$ & $\begin{array}{c}-21,511^{*} \\
(0,000)\end{array}$ & $\begin{array}{r}-16,184^{*} \\
(0,000)\end{array}$ & $\begin{array}{c}77,213^{*} \\
(0,000)\end{array}$ & $\begin{array}{r}174,494^{*} \\
(0,000)\end{array}$ \\
\hline$\Delta \mathrm{CO}$ & $\begin{array}{c}-16,027^{*} \\
(0,000)\end{array}$ & $\begin{array}{c}-13,915^{*} \\
(0,000)\end{array}$ & $\begin{array}{c}-14,681^{*} \\
(0,000)\end{array}$ & $\begin{array}{c}-12,698^{*} \\
(0,000)\end{array}$ & $\begin{array}{c}153,828 * \\
(0,000)\end{array}$ & $\begin{array}{r}124,905 * \\
(0,000)\end{array}$ \\
\hline$\Delta$ NDS & $\begin{array}{r}-10,152 * \\
(0,000)\end{array}$ & $\begin{array}{l}-9,233^{*} \\
(0,000)\end{array}$ & $\begin{array}{c}-10,230 * \\
(0,000)\end{array}$ & $\begin{array}{l}-9,339 * \\
(0,000)\end{array}$ & $\begin{array}{c}107,271^{*} \\
(0,000)\end{array}$ & $\begin{array}{c}92,924^{*} \\
(0,000)\end{array}$ \\
\hline$\Delta$ FAiz & $\begin{array}{c}-1,944 * * \\
(0,025)\end{array}$ & $\begin{array}{l}-9,010 * \\
(0,000)\end{array}$ & $\begin{array}{c}-5,830 * \\
(0,000)\end{array}$ & $\begin{array}{l}-7,843^{*} \\
(0,000)\end{array}$ & $\begin{array}{l}52,466^{*} \\
(0,000)\end{array}$ & $\begin{array}{c}67,836 * \\
(0,000)\end{array}$ \\
\hline$\Delta$ TÜFE & $\begin{array}{l}-8,978^{*} \\
(0,000)\end{array}$ & $\begin{array}{r}-8,928 * \\
(0,000)\end{array}$ & $\begin{array}{l}-8,702^{*} \\
(0,000)\end{array}$ & $\begin{array}{l}-8,979 * \\
(0,000)\end{array}$ & $\begin{array}{r}85,640 * \\
(0,000)\end{array}$ & $\begin{array}{r}81,528 * \\
(0,000)\end{array}$ \\
\hline$\Delta K U R$ & $\begin{array}{c}-5,146^{*} \\
(0,000)\end{array}$ & $\begin{array}{l}-3,713^{*} \\
(0,000)\end{array}$ & $\begin{array}{l}-7,544^{*} \\
(0,000)\end{array}$ & $\begin{array}{c}-6,376^{*} \\
(0,000)\end{array}$ & $\begin{array}{c}71,949 * \\
(0,000)\end{array}$ & $\begin{array}{c}54,779 * \\
(0,000)\end{array}$ \\
\hline$\Delta \mathrm{M} 2$ & $\begin{array}{c}-11,637^{*} \\
(0,000)\end{array}$ & $\begin{array}{c}-12,196 * \\
(0,000)\end{array}$ & $\begin{array}{c}-10,269 * \\
(0,000)\end{array}$ & $\begin{array}{c}-10,493^{*} \\
(0,000)\end{array}$ & $\begin{array}{c}102,610^{*} \\
(0,000)\end{array}$ & $\begin{array}{c}95,543^{*} \\
(0,000)\end{array}$ \\
\hline$\Delta$ GSYH & $\begin{array}{l}-9,652^{*} \\
(0,000)\end{array}$ & $\begin{array}{c}-8,843^{*} \\
(0,000)\end{array}$ & $\begin{array}{l}-8,615^{*} \\
(0,000)\end{array}$ & $\begin{array}{l}-7,503^{*} \\
(0,000)\end{array}$ & $\begin{array}{c}82,896 * \\
(0,000)\end{array}$ & $\begin{array}{c}64,415^{*} \\
(0,000)\end{array}$ \\
\hline$\triangle$ SAN & $\begin{array}{c}-11,969 * \\
(0,000)\end{array}$ & $\begin{array}{c}-11,505^{*} \\
(0,000)\end{array}$ & $\begin{array}{l}-9,821^{*} \\
(0,000)\end{array}$ & $\begin{array}{c}-8,815^{*} \\
(0,000)\end{array}$ & $\begin{array}{c}97,243^{*} \\
(0,000)\end{array}$ & $\begin{array}{c}77,799 * \\
(0,000)\end{array}$ \\
\hline
\end{tabular}

$\Delta$, birinci fark işlemcisidir. Parantez içindeki değerler, olasılık değerlerini göstermektedir.

$*,{ }^{* *}$ ve ${ }^{* * *}$, sırasıyla $\% 1, \% 5$ ve $\% 10$ düzeylerinde anlamlılığı ifade etmektedir. 
Panel birim kök testlerine ait analiz sonuçları (Tablo 4) incelendiğinde, genel olarak değişkenlerin düzeyde durağan olmadıkları ancak ilk farkında durağan oldukları görülmektedir.

\subsubsection{Panel Eşbütünleşme Testleri}

Çalışmanın bu bölümünde panel veri setinde yer alan bağımlı ve bağımsız değişkenler arasındaki uzun dönem eşbütünleşme ilişkisinin test edilmesinde Pedroni (1999 ve 2004) tarafından önerilen ve temel hipotezi "eş bütünleşme yoktur" şeklindeki panel eşbütünleşme testi kullanılmıştır. Panel eşbütünleşme testi sonucundan değişkenler arasında uzun dönemli ilişki bulunmuşsa, eşbütünleşme ilişkisinin varlığı bağımsız değişkenlere ait uzun dönem katsayılarının tahmin edilmesini gerektirmektedir. Pedroni $(2000,2001)$ tarafından geliştirilen FMOLS ampirik analizlerde yaygın olarak kullanılan bir yöntemdir.

Pedroni yaklaşımında sıfır ve alternatif hipotezler şu şekilde tanımlanmıştır

$\mathrm{H}_{0}$ : Bütün yatay kesitler için eşbütünleşme ilişkisi yoktur.

$\mathrm{H}_{1}$ : Bütün yatay kesitler için eşbütünleşme ilişkisi vardır.

Pedroni, bu hipotezlerin sınanması için yedi adet panel eş bütünleşme testi (dördü panel ve üçü grup test istatistiği) önermiştir. Bu testlerin dördü kesit-içi, diğerleri kesitler-arası panel eşbütünleşme testleri olarak adlandırılmaktadır (Pedroni, 1999: 660).

Panel eşbütünleşme testi sonuçları Tablo 5'te gösterilmektedir. Pedroni testlerinin çoğu Nakit Dönüşüm Süresi (NDS) hariç diğer tüm modellerde eşbütünleşme ilişkisi olduğunu göstermektedir.

Tablo 5'teki sonuçlara göre, ele alınan panel veri setleri için sıfır hipotezi $\left(H_{0}\right)$ dört model için reddedilmekte; böylece, eşbütünleşme olduğu sonucuna ulaşılmaktadır. Çalışmada sadece "Nakit Dönüşüm Süresi" (Model 4) için sıfır hipotezi $\left(H_{0}\right)$ reddedilmemiş diğer bağımlı değişkenler için sıfır hipotezi $\left(H_{0}\right)$ reddedilmiştir. Değişkenler arasında uzun dönem eşbütünleşme ilişkisinin varlığının tespit edilmesi açıklayıcı değişkenlere ait uzun dönem katsayıların tahminini gerektirmektedir. 
Tablo 5: Panel Eşbütünleşme Test Sonuçları

\begin{tabular}{|c|c|c|c|c|c|c|c|}
\hline $\begin{array}{c}\text { Pedroni } \\
\text { (1999) }\end{array}$ & $\begin{array}{c}\text { Panel- } \\
\text { v }\end{array}$ & $\begin{array}{c}\text { Panel- } \\
\text { rho }\end{array}$ & $\begin{array}{c}\text { Panel- } \\
\text { PP } \\
\end{array}$ & $\begin{array}{l}\text { Panel- } \\
\text { ADF }\end{array}$ & $\begin{array}{c}\text { Group- } \\
\text { rho } \\
\end{array}$ & $\begin{array}{c}\text { Group- } \\
\text { PP } \\
\end{array}$ & $\begin{array}{c}\text { Group- } \\
\text { ADF }\end{array}$ \\
\hline \multicolumn{8}{|l|}{ CAA } \\
\hline Sabitli & $\begin{array}{l}-0,681 \\
(0,752) \\
\end{array}$ & $\begin{array}{l}-0,167 \\
(0,433)\end{array}$ & $\begin{array}{l}-2,497^{*} \\
(0,006)\end{array}$ & $\begin{array}{l}-3,723^{*} \\
(0,000)\end{array}$ & $\begin{array}{l}-0,086 \\
(0,465) \\
\end{array}$ & $\begin{array}{l}-3,159^{*} \\
(0,000)\end{array}$ & $\begin{array}{l}-4,075^{*} \\
(0,000)\end{array}$ \\
\hline Sabitli-Trendli & $\begin{array}{r}-1,043 \\
(0,851) \\
\end{array}$ & $\begin{array}{c}0,572 \\
(0,716) \\
\end{array}$ & $\begin{array}{l}-3,401^{*} \\
(0,000) \\
\end{array}$ & $\begin{array}{l}-5,103^{*} \\
(0,000) \\
\end{array}$ & $\begin{array}{r}0,535 \\
(0,703) \\
\end{array}$ & $\begin{array}{l}-3,936^{*} \\
(0,000) \\
\end{array}$ & $\begin{array}{l}-5,316^{*} \\
(0,000)\end{array}$ \\
\hline \multicolumn{8}{|l|}{$\underline{\mathrm{ADH}}$} \\
\hline Sabitli & $\begin{array}{r}1,189 \\
(0,117)\end{array}$ & $\begin{array}{c}-1,424^{* * *} \\
(0,077)\end{array}$ & $\begin{array}{r}-32,193^{*} \\
(0,000)\end{array}$ & $\begin{array}{r}-25,932^{*} \\
(0,000)\end{array}$ & $\begin{array}{l}-0,679 \\
(0,248)\end{array}$ & $\begin{array}{r}-35,922^{*} \\
(0,000)\end{array}$ & $\begin{array}{r}-27,809^{*} \\
(0,000)\end{array}$ \\
\hline Sabitli-Trendli & $\begin{array}{c}0,017 \\
(0,493) \\
\end{array}$ & $\begin{array}{l}-0,928 \\
(0,176) \\
\end{array}$ & $\begin{array}{r}-25,816^{*} \\
(0,000) \\
\end{array}$ & $\begin{array}{c}-23,734^{*} \\
(0,000) \\
\end{array}$ & $\begin{array}{r}-0,254 \\
(0,399) \\
\end{array}$ & $\begin{array}{r}-26,625^{*} \\
(0,000) \\
\end{array}$ & $\begin{array}{r}-24,281^{*} \\
(0,000) \\
\end{array}$ \\
\hline \multicolumn{8}{|l|}{$\underline{\mathrm{SDH}}$} \\
\hline Sabitli & $\begin{array}{c}0,857 \\
(0,195) \\
\end{array}$ & $\begin{array}{c}-1,417^{* * *} \\
(0,078) \\
\end{array}$ & $\begin{array}{r}-24,409^{*} \\
(0,000) \\
\end{array}$ & $\begin{array}{r}-21,570^{*} \\
(0,000) \\
\end{array}$ & $\begin{array}{r}-0,941 \\
(0,173) \\
\end{array}$ & $\begin{array}{r}-24,105^{*} \\
(0,000) \\
\end{array}$ & $\begin{array}{r}-24,516^{*} \\
(0,000) \\
\end{array}$ \\
\hline Sabitli-Trendli & $\begin{array}{l}-0,317 \\
(0,624)\end{array}$ & $\begin{array}{l}-0,780 \\
(0,217)\end{array}$ & $\begin{array}{r}-22,991^{*} \\
(0,000)\end{array}$ & $\begin{array}{r}-21,379^{*} \\
(0,000)\end{array}$ & $\begin{array}{l}-0,221 \\
(0,412)\end{array}$ & $\begin{array}{c}-1,741^{* *} \\
(0,040)\end{array}$ & $\begin{array}{r}-24,516^{*} \\
(0,000)\end{array}$ \\
\hline \multicolumn{8}{|l|}{$\underline{\text { NDS }}$} \\
\hline Sabitli & $\begin{array}{r}-1,278 \\
(0,899) \\
\end{array}$ & $\begin{array}{c}1,150 \\
(0,875) \\
\end{array}$ & $\begin{array}{l}-0,110 \\
(0,456) \\
\end{array}$ & $\begin{array}{l}-0,323 \\
(0,373) \\
\end{array}$ & $\begin{array}{r}2,040 \\
(0,979) \\
\end{array}$ & $\begin{array}{c}-1,741^{* *} \\
(0,040) \\
\end{array}$ & $\begin{array}{c}-1,286^{* * *} \\
(0,099) \\
\end{array}$ \\
\hline Sabitli-Trendli & $\begin{array}{r}-2,141 \\
(0,983) \\
\end{array}$ & $\begin{array}{c}1,927 \\
(0,973) \\
\end{array}$ & $\begin{array}{c}0,276 \\
(0,608) \\
\end{array}$ & $\begin{array}{l}-0,047 \\
(0,480) \\
\end{array}$ & $\begin{array}{r}2,755 \\
(0,997) \\
\end{array}$ & $\begin{array}{r}-1,065 \\
(0,143) \\
\end{array}$ & $\begin{array}{c}0,062 \\
(0,524) \\
\end{array}$ \\
\hline \multicolumn{8}{|l|}{$\underline{\mathrm{CO}}$} \\
\hline Sabitli & $\begin{array}{r}-1,060 \\
(0,855) \\
\end{array}$ & $\begin{array}{l}-0,538 \\
(0,295) \\
\end{array}$ & $\begin{array}{l}-3,116^{*} \\
(0,000) \\
\end{array}$ & $\begin{array}{l}-3,208^{*} \\
(0,000)\end{array}$ & $\begin{array}{r}-0,130 \\
(0,448) \\
\end{array}$ & $\begin{array}{l}-4,280^{*} \\
(0,000) \\
\end{array}$ & $\begin{array}{l}-4,233^{*} \\
(0,000)\end{array}$ \\
\hline Sabitli-Trendli & $\begin{array}{r}-1,875 \\
(0,969)\end{array}$ & $\begin{array}{c}0,406 \\
(0,657)\end{array}$ & $\begin{array}{l}-2,836^{*} \\
(0,002)\end{array}$ & $\begin{array}{l}-2,975^{*} \\
(0,001)\end{array}$ & $\begin{array}{r}0,865 \\
(0,806)\end{array}$ & $\begin{array}{l}-5,414^{*} \\
(0,000)\end{array}$ & $\begin{array}{l}-3,712^{*} \\
(0,000)\end{array}$ \\
\hline
\end{tabular}

Parantez içindeki değerler, olasılık değerlerini göstermektedir.

*, ** ve ***, sırasıyla \%1, \%5 ve \%10 düzeylerinde anlamlılığı ifade etmektedir. 


\subsubsection{Panel Eşbütünleşme iliş̧kisi (Uzun Dönem Katsayıları) Tahmini}

Eşbütünleşme ilişkisinin varlığı tespit edildikten sonra, eşbütünleşme ilişkisinde bağımsız değişkenlere ait uzun dönem katsayılarının tahmin edilmesi gerekmektedir. Literatürde, bu amaçla geliştirilen ve eşbütünleşme vektörünün tahmin edilmesini sağlayan çeşitli yöntemler yer almaktadır. Bu çalışmada, Pedroni (2000) tarafından geliştirilen Grup Ortalama Panel Tam Uyarlanmış En Küçük Kareler (FMOLS-Fully Modified Ordinary Least Squares) yönteminden faydalanılmaktadır.

Pedroni (2000) tarafından geliştirilen grup ortalama panel FMOLS yöntemi aşağıdaki panel regresyon modeline dayanmaktadır.

$$
\begin{aligned}
& y_{i t}=a_{i}+\beta x_{i t}+\mu_{i t} \\
& x_{i t}=x_{i t-1}+\varepsilon_{i t}
\end{aligned}
$$

Burada $y_{i t}$ bağımlı değişkeni, $x_{i t}$ bağımsız değişkenleri ve $a_{i}$ için sabit etkileri göstermektedir. Eşitlik (1)'de $y_{i t}$ ve $x_{i t}$ arasında uzun dönem eşbütünleşme ilişkisi vardır ve hata terimleri durağan bir sürece sahiptir. Böylece, $\beta$ tahmin edilmesi gereken uzun dönem eşbütünleşme vektörünü göstermektedir. Panel FMOLS tahmincisinde panel için eşbütünleşme vektörü elde edilirken birinci aşamada Eşitlik (1)'deki model her bir yatay kesit için FMOLS tahmincisi (Newey-West tahmincisi) kullanılarak tahmin edilmektedir. İkinci aşamada her bir yatay kesite ait FMOLS tahmininden elde edilen eşbütünleşme katsayılarının ortalaması alınmakta ve panel için eşbütünleşme katsayısı şu şekilde hesaplanmaktadır:

$$
\hat{\beta}_{G F M}^{*}=N^{-1} \sum_{i=1}^{N} \beta_{F M, i}^{*}
$$

Burada $\beta_{F M, i}^{*}$ her bir yatay kesit için FMOLS tahmininden elde edilen eşbütünleşme katsayısını göstermektedir. Grup ortalama panel FMOLS tahmincilerine ait tistatistikleri her bir yatay kesit için FMOLS tahmininden elde edilen eşbütünleşme katsayısına ait t-istatistiklerinden elde edilmekte ve aşağıdaki gibi hesaplanmaktadır:

$$
{ }^{t} \hat{\beta}_{G F M}^{*}=N^{-1 / 2} \sum_{i=1}^{N} t \hat{\beta}_{F M, i}^{*}
$$


Burada $t_{\hat{\beta}_{F M, i}^{*}}^{*}$ ise paneli oluşturan her bir yatay kesit için yapılan FMOLS tahmininden elde edilen eşbütünleşme katsayısına ilişkin t-istatistiğini göstermektedir (Pedroni, 2001: 729).

$\mathrm{Bu}$ açıklamalar doğrultusunda makroekonomik değişkenlerin sektörlerin işletme sermayesi üzerindeki uzun dönem etkilerini analiz etmek için Pedroni tarafından (2000)'de geliştirilen panel FMOLS tahmincileri kullanılmıştır. Makroekonomik değişkenler (faiz oranları, tüketici fiyatları endeksi, döviz kuru, para arzı, gayrisafi yurtiçi hâsıla ve sanayi üretim endeksi) bazında sektörlere ait FMOLS tahmincisi ile elde edilen eşbütünleşme katsayıları tahminleri sırasıyla şöyledir:

Faiz oranları, tüketicilerin tüketim kararlarını ve nakit akımlarını, üreticilerin ise yatırım ve harcama kararlarını etkilemekte ve ekonomideki toplam talebi değiştirmektedir. Faiz oranlarının sektörlerin işletme sermayesi üzerindeki uzun dönem etkileri Tablo 6'da verilmiştir.

Tablo 6: Faiz Oranları İçin Eşbütünleşme Katsayısı Tahmini

\begin{tabular}{|c|c|c|c|c|c|}
\hline Sektör & $\begin{array}{c}\text { Model } 1 \\
\text { (CAA) }\end{array}$ & $\begin{array}{c}\text { Model } 2 \\
\text { (ADH) }\end{array}$ & $\begin{array}{c}\text { Model } 3 \\
\text { (SDH) }\end{array}$ & $\begin{array}{c}\text { Model } 4 \\
\text { (NDS) }\end{array}$ & $\begin{array}{l}\text { Model } 5 \\
\text { (CO) }\end{array}$ \\
\hline Metal & $\begin{array}{l}-0,617^{*} \\
(0,000) \\
\end{array}$ & $\begin{array}{c}-0,035^{* * *} \\
(0,074) \\
\end{array}$ & $\begin{array}{c}0,014 \\
(0,190) \\
\end{array}$ & \multirow{7}{*}{ 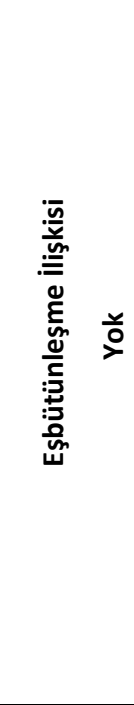 } & $\begin{array}{l}-0,017^{*} \\
(0,000) \\
\end{array}$ \\
\hline Gıda & $\begin{array}{l}0,311^{*} \\
(0,000)\end{array}$ & $\begin{array}{l}-0,015 \\
(0,291)\end{array}$ & $\begin{array}{l}0,139 * \\
(0,000)\end{array}$ & & $\begin{array}{l}-0,031^{*} \\
(0,000)\end{array}$ \\
\hline Kimya & $\begin{array}{l}0,610^{*} \\
(0,000)\end{array}$ & $\begin{array}{l}-0,094^{*} \\
(0,001) \\
\end{array}$ & $\begin{array}{c}-0,066^{* *} \\
(0,025)\end{array}$ & & $\begin{array}{l}-0,038^{*} \\
(0,000)\end{array}$ \\
\hline Tekstil & $\begin{array}{l}0,481^{*} \\
(0,000)\end{array}$ & $\begin{array}{l}-0,009 \\
(0,277)\end{array}$ & $\begin{array}{l}-0,037^{*} \\
(0,000)\end{array}$ & & $\begin{array}{l}-0,055^{*} \\
(0,000)\end{array}$ \\
\hline Teknoloji & $\begin{array}{l}0,397^{*} \\
(0,000) \\
\end{array}$ & $\begin{array}{l}-0,103 * \\
(0,000) \\
\end{array}$ & $\begin{array}{r}0,022 \\
(0,235)\end{array}$ & & $\begin{array}{l}0,006 \\
(0,178) \\
\end{array}$ \\
\hline Panel & $0,227^{*}$ & $-0,051^{*}$ & 0,001 & & $-0,013^{*}$ \\
\hline FMOLS & $(0,000)$ & $(0,000)$ & $(0,822)$ & & $(0,000)$ \\
\hline
\end{tabular}

Parantez içindeki değerler, olasılık değerlerini göstermektedir.

$*, * *$ ve $* * *$, sırasıyla $\% 1, \% 5$ ve $\% 10$ düzeylerinde anlamlılığı ifade etmektedir.

Tablo 6 incelendiğinde panel FMOLS sonuçlarına göre faiz oranları ile Model 1 arasında pozitif ve anlamlı, Model 2 ve Model 5 arasında negatif ve anlamlı ilişki tespit edilmiş ancak Model 3 arasında ilişki bulunamamıştır. Ayrıca bütün makroekonomik 
değişkenler için Model 4'te (Nakit Dönüşüm Modeli) uzun dönem eşbütünleşme ilişkisi bulunmadığından katsayı tahmini yapılamamıştır.

Faiz oranlarının arttığı dönemlerde sektörlerin toplam varlıklar içindeki dönen varlık payı artmaktadır ki bu durum firmaların ihtiyatlılık gereği aldığı önlemlerden biri olarak değerlendirilebilir. Faiz oranları ile Model 1 arasındaki sonuç, bu durumu desteklemektedir. Ayrıca, faiz oranları ile cari oran arasında negatif bir ilişki bulunmaktadır. Bu durum, firmaların faiz oranlarının arttığı dönemde kısa vadeli borçlarının dönen varlıklarından daha yavaş arttığını göstermekte ve birinci modelin bulgularını desteklemektedir. Faiz oranlarının yükseldiği dönemlerde ekonomiye yönelik beklentiler olumsuz yönde olacağından işletmelerin net satışlarında azalma görülecek, alacakların tahsilat hızı azalacak ve bu durumda alacak devir hızı faiz oranlarındaki artıştan negatif yönde etkilenecektir. Faiz oranları ile Model 2 arasındaki sonuç bunu destekler niteliktedir.

Enflasyon, planlama ufkunu daralttığı için sağlıklı yatırım ve üretim kararları alınamayacağından uzun vadeli planlar yapılamaz. Tüketici fiyatları endeksinin sektörlerin işletme sermayesi üzerindeki uzun dönem etkileri Tablo 7’ye göre şöyledir: Tüketici fiyatları endeksi ile Model 1 arasında pozitif ve anlamlı, Model 2 ve Model 3 arasında negatif ve anlamlı ilişki tespit edilmiş ancak Model 5 arasında istatistiki olarak anlamlı bir ilişki bulunamamıştır.

Fiyatların artması bireylerin reel olarak tüketimlerini azaltacağından işletmelerin net satışlarında azalma görülmektedir. Bu dönemler genel ekonomik durgunluğun yaşandığı, satın alma eğilimindeki düşüşlerin ve alacak tahsilat sürelerinin uzadığı dönemlerdir. Tablo 7'de tüketici fiyatları endeksi ile Model 2 ve Model 3 arasındaki sonuca göre alacak ve stok devir hızı düşmüştür.

Tablo 7: Tüketici Fiyatları İçin Endeksi Eşbütünleşme Katsayısı Tahmini

\begin{tabular}{|c|c|c|c|c|c|}
\hline Model & $\begin{array}{c}\text { Model } 1 \\
\text { (CAA) }\end{array}$ & $\begin{array}{c}\text { Model } 2 \\
\text { (ADH) }\end{array}$ & $\begin{array}{c}\text { Model } 3 \\
\text { (SDH) }\end{array}$ & $\begin{array}{c}\text { Model } 4 \\
\text { (NDS) }\end{array}$ & $\begin{array}{c}\text { Model } 5 \\
\text { (CO) }\end{array}$ \\
\hline Metal & $\begin{array}{l}0,362^{*} \\
(0,000) \\
\end{array}$ & $\begin{array}{l}-0,068^{*} \\
(0,001) \\
\end{array}$ & $\begin{array}{l}-0,092 * \\
(0,000) \\
\end{array}$ & \multirow{5}{*}{ 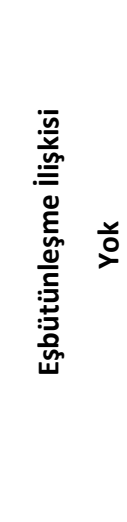 } & $\begin{array}{c}0,004^{* * *} \\
(0,064)\end{array}$ \\
\hline Gıda & $\begin{array}{l}-0,059 \\
0,409\end{array}$ & $\begin{array}{l}-0,170 * \\
(0,000)\end{array}$ & $\begin{array}{l}-0,068 * \\
(0,000)\end{array}$ & & $\begin{array}{l}0,018^{*} \\
(0,000)\end{array}$ \\
\hline Kimya & $\begin{array}{l}-0,018 \\
(0,770) \\
\end{array}$ & $\begin{array}{l}-0,147^{*} \\
(0,000) \\
\end{array}$ & $\begin{array}{l}-0,110^{*} \\
(0,001) \\
\end{array}$ & & $\begin{array}{l}-0,004 \\
(0,461) \\
\end{array}$ \\
\hline Tekstil & $\begin{array}{l}0,249 * \\
(0,005)\end{array}$ & $\begin{array}{l}-0,063^{*} \\
(0,000) \\
\end{array}$ & $\begin{array}{l}-0,072^{*} \\
(0,000) \\
\end{array}$ & & $\begin{array}{l}0,041^{*} \\
(0,000)\end{array}$ \\
\hline Teknoloji & $-0,059$ & $-0,074^{*}$ & $-0,044 * *$ & & $-0,007$ \\
\hline
\end{tabular}




\begin{tabular}{|c|c|c|c|c|}
\hline & $(0,337)$ & $(0,000)$ & $(0,045)$ & $(0,176)$ \\
\hline Panel & $0,100^{*}$ & $-0,105^{*}$ & $-0,099 *$ & 0,004 \\
\hline FMOLS & $(0,002)$ & $(0,000)$ & $(0,000)$ & $(0,116)$ \\
\hline
\end{tabular}

Parantez içindeki değerler, olasılık değerlerini göstermektedir.

*, ** ve ***, sırasıyla $\% 1, \% 5$ ve $\% 10$ düzeylerinde anlamlılığı ifade etmektedir.

Enflasyon dönemlerinde parasal değerler reel olarak değer kaybedeceğinden mevcut fonlar reel kıymetlere (stoklar, sabit varlıklar) kaydırılır. Bu sebepten dolayı işletme sermayesi ihtiyacına bağlı olarak işletmelerin sermaye talepleri artmaktadır. Tüketici fiyatları endeksi ile Model 1 arasındaki pozitif yönlü ilişki bu durumu destekler niteliktedir.

Çalışmada döviz kuru olarak reel efektif döviz kuru esas alınmış olup, TCMB tanımlarıyla tutarlı olarak, reel kur artışları ülke parasının reel olarak değer kazanması anlamına gelmektedir. Reel efektif döviz kurunun sektörlerin işletme sermayesi üzerindeki uzun dönem etkileri Tablo 8'de verilmiştir. Tablo 8 incelendiğinde panel FMOLS sonuçları döviz kuru ile Model 1 ve Model 2 arasında pozitif ve anlamlı, Model 3 arasında negatif ve anlamlı ilişki olduğunu göstermektedir. Yine tabloya göre döviz kuru ile Model 5 arasında istatistiki olarak anlamlı bir ilişki bulunamamıştır.

Tablo 8: Döviz Kuru İçin Eşbütünleşme Katsayısı Tahmini

\begin{tabular}{|c|c|c|c|c|c|}
\hline Sektör & $\begin{array}{c}\text { Model } 1 \\
\text { (CAA) }\end{array}$ & $\begin{array}{c}\text { Model } 2 \\
\text { (ADH) }\end{array}$ & $\begin{array}{c}\text { Model } 3 \\
\text { (SDH) }\end{array}$ & $\begin{array}{c}\text { Model } 4 \\
\text { (NDS) }\end{array}$ & $\begin{array}{c}\text { Model } 5 \\
\text { (CO) }\end{array}$ \\
\hline Metal & $\begin{array}{l}0,217^{*} \\
(0,000) \\
\end{array}$ & $\begin{array}{l}-0,007 \\
(0,550) \\
\end{array}$ & $\begin{array}{l}-0,025^{*} \\
(0,000) \\
\end{array}$ & \multirow{7}{*}{ 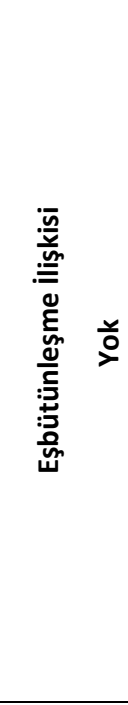 } & $\begin{array}{l}-0,015^{*} \\
(0,000) \\
\end{array}$ \\
\hline Gıda & $\begin{array}{l}0,177^{*} \\
(0,000) \\
\end{array}$ & $\begin{array}{c}0,012 \\
(0,147) \\
\end{array}$ & $\begin{array}{l}0,047^{*} \\
(0,000) \\
\end{array}$ & & $\begin{array}{l}-0,001 \\
(0,613) \\
\end{array}$ \\
\hline Kimya & $\begin{array}{l}0,094 * * \\
(0,010)\end{array}$ & $\begin{array}{l}0,054^{*} \\
(0,002)\end{array}$ & $\begin{array}{l}0,068^{*} \\
(0,000)\end{array}$ & & $\begin{array}{l}0,011^{*} \\
(0,001)\end{array}$ \\
\hline Tekstil & $\begin{array}{l}-0,158^{*} \\
(0,001)\end{array}$ & $\begin{array}{c}0,006 \\
(0,230) \\
\end{array}$ & $\begin{array}{l}0,013 * \\
(0,001)\end{array}$ & & $\begin{array}{l}0,004 * * \\
(0,027)\end{array}$ \\
\hline Teknoloji & $\begin{array}{l}-0,105 * \\
(0,003)\end{array}$ & $\begin{array}{c}-0,016^{* *} \\
(0,019)\end{array}$ & $\begin{array}{l}-0,065^{*} \\
(0,000)\end{array}$ & & $\begin{array}{l}-0,010^{*} \\
(0,001)\end{array}$ \\
\hline Panel & $0,090 *$ & $0,010 * *$ & $-0,009 * * *$ & & 0,001 \\
\hline FMOLS & $(0,000)$ & $(0,020)$ & $(0,072)$ & & $(0,226)$ \\
\hline
\end{tabular}

Parantez içindeki değerler, olasılık değerlerini göstermektedir.

$*, * *$ ve $* * *$, sırasıyla $\% 1, \% 5$ ve $\% 10$ düzeylerinde anlamlılığı ifade etmektedir. 
TL'nin değeri girdi ve finansman maliyetleri açısından önemlidir. TL'nin değer kaybetmesi durumunda ithal edilen malların TL cinsinden fiyatları arttığı için üretim maliyetleri artacak ve üretim daha pahalı hale gelecektir. İşletmelerin üretim maliyetlerinde artış olması ve bunun fiyatlara yansıması kaçınılmaz bir gerçektir. Böyle bir durumda işletmelerin stok tutma süresinin uzaması beklenebilir. Tablo 8'e göre döviz kuru ile Model 3 arasında negatif ve anlamlı ilişki bulunması bu beklentiyi desteklemektedir. Döviz kuru ile Model 1 arasında pozitif ilişki değerlendirildiğinde, çalışma sermayesi payının stok devir hızına bağlı olarak arttığını söylemek mümkündür.

Tablo 9: Para Arzı İçin Eşbütünleşme Katsayısı Tahmini

\begin{tabular}{|c|c|c|c|c|c|}
\hline Sektör Model & $\begin{array}{l}\text { Model } 1 \\
\text { (CAA) }\end{array}$ & $\begin{array}{c}\text { Model } 2 \\
\text { (ADH) }\end{array}$ & $\begin{array}{c}\text { Model } 3 \\
\text { (SDH) }\end{array}$ & $\begin{array}{l}\text { Model } 4 \\
\text { (NDS) }\end{array}$ & $\begin{array}{l}\text { Model } 5 \\
\text { (CO) }\end{array}$ \\
\hline \multirow{2}{*}{ Metal } & $-0,001^{*}$ & $0,001 * *$ & $0,001^{*}$ & \multirow{12}{*}{ 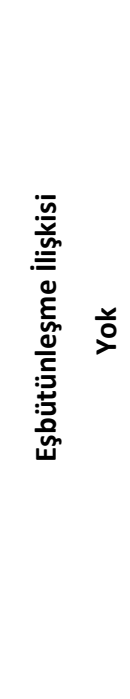 } & $-0,001 * *$ \\
\hline & $(0,000)$ & $(0,029)$ & $(0,000)$ & & $(0,018)$ \\
\hline \multirow{2}{*}{ Gıda } & $0,001^{*}$ & $0,001^{*}$ & $0,001^{*}$ & & $-0,001^{*}$ \\
\hline & $(0,000)$ & $(0,000)$ & $(0,000)$ & & $(0,000)$ \\
\hline \multirow{2}{*}{ Kimya } & 0,001 & $0,001^{*}$ & 0,001 & & $-0,001 *$ \\
\hline & $(0,254)$ & $(0,000)$ & $(0,124)$ & & $(0,007)$ \\
\hline \multirow{2}{*}{ Tekstil } & $-0,001^{*}$ & $0,001^{*}$ & $0,001^{*}$ & & $-0,001^{*}$ \\
\hline & $(0,000)$ & $(0,000)$ & $(0,000)$ & & $(0,000)$ \\
\hline \multirow{2}{*}{ Teknoloji } & $-0,001^{*}$ & $0,001^{*}$ & 0,001 & & $0,001^{* *}$ \\
\hline & $(0,000)$ & $(0,003)$ & $(0,199)$ & & $(0,047)$ \\
\hline Panel & $-0,001 *$ & $0,001 *$ & $0,001^{*}$ & & $-0,001^{*}$ \\
\hline FMOLS & $(0,000)$ & $(0,000)$ & $(0,000)$ & & $(0,000)$ \\
\hline
\end{tabular}

Parantez içindeki değerler, olasılık değerlerini göstermektedir.

$*, * *$ ve $* * *$, sırasıyla $\% 1, \% 5$ ve $\% 10$ düzeylerinde anlamlılığı ifade etmektedir.

Tablo 9'da panel FMOLS sonuçlarına göre para arzı ile Model 2 ve Model 3 arasında pozitif ve anlamlı, Model 1 ve Model 5 arasında negatif ve anlamlı ilişki tespit edilmiştir.

Para arzı arttığında kısa vadede faizler düşer, yatırımlar artar. Bununla birlikte bireylerin sahip oldukları para miktarı arttığından harcama eğilimleri de yükselir. Para arzı artışları, reel üretimde artışa yol açtığı anlamına gelmektedir. Para arzının arttığı dönemler genişletici para politikasının etkin olduğu dönemlerdir. Bu dönemlerde işletmelerin satış hacimleri artmakta, stok tutma süreleri kısalmakta ve alacak tahsilat hızları artmaktadır. Bu sonuçları, para arzı ile ikinci model olan alacak devir hızı ve üçüncü model olan stok devir hızı modeli arasındaki pozitif ilişki desteklemektedir. Bu durum aynı zamanda işletme sermayesi unsuru olan alacak ve stok kalemlerinde azalış anlamına gelmekte olup para arzı ile Model 1 arasındaki negatif yönlü ilişki tarafından da desteklenmektedir. Genişletici para politikasının sonucu olarak işletmelerin dış 
kaynaklara erişimi kolaylaşmakta ve işletmelerin finansman tercihlerini düşen faiz oranlarını göz önünde bulundurarak borçlanma yönünde yapmaları borçlanmayı artırmakta dolayısıyla da cari oran negatif etkilenmektedir. Para arzı ile Model 5 arasındaki negatif yönlü ilişkiyi bu şekilde yorumlamak mümkündür.

Tablo 10'daki panel FMOLS sonuçları incelendiğinde, gayrisafi yurtiçi hâsıla ile bütün modeller arasında pozitif yönlü bir ilişki tespit edilmiştir. Bir ekonomide gayrisafi yurtiçi hâsıla arttıkça bireylerin kullanılabilir gelirleri dolayısıyla da mal ve hizmetlere olan taleplerinde artış beklenir. Ekonomik canlılıkla beraber işletmelerin satış hacimleri artacak ve işletmeler kredili satışlarda daha istekli davranacaklardır. Gayrisafi yurtiçi hâsıla ile Model 2 ve Model 3 arasındaki pozitif yönlü ilişkiye göre GSYH'deki artış alacak ve stok devir hızını artırmaktadır. Ayrıca satış ve satışa bağlı olarak üretim hacminin artmasından dolayı işletmeler daha fazla stokla çalışmak zorunda kalmaktadırlar. Bu durumda GSYH ile Model 1 arasındaki pozitif ilişkiye göre işletme sermayesi payı artmaktadır demek mümkündür. Birinci modele göre artan bir işletme sermayesi ihtiyacı vardır ve bu durumda cari oran pozitif yönde etkilenmektedir. Ancak ekonomik canlılığın verdiği güvenle kredi kuruluşlarının kredi verme konusunda daha istekli davranmaları, işletmelerin artan işletme sermayesi intiyaçlarını karşılamada bu kaynaklardan yararlanmaları kısa vadeli borç kullanımını artıracaktır. Bu durumda ise cari oran negatif yönde etkilenecektir.

Tablo 10: GSYH İçin Eşbütünleşme Katsayısı Tahmini

\begin{tabular}{|c|c|c|c|c|c|}
\hline Sektör Model & $\begin{array}{l}\text { Model } 1 \\
\text { (CAA) }\end{array}$ & $\begin{array}{l}\text { Model } 2 \\
\text { (ADH) }\end{array}$ & $\begin{array}{c}\text { Model } 3 \\
\text { (SDH) }\end{array}$ & $\begin{array}{l}\text { Model } 4 \\
\text { (NDS) }\end{array}$ & $\begin{array}{l}\text { Model } 5 \\
\text { (CO) }\end{array}$ \\
\hline \multirow{2}{*}{ Metal } & $-0,001^{*}$ & $0,001^{*}$ & $0,001^{*}$ & \multirow{12}{*}{ 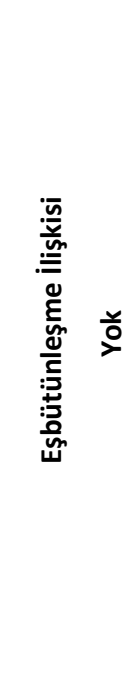 } & $-0,001^{*}$ \\
\hline & $(0,000)$ & $(0,000)$ & $(0,000)$ & & $(0,000)$ \\
\hline \multirow{2}{*}{ Gıda } & $-0,001^{*}$ & $0,001^{*}$ & $0,001^{*}$ & & $-0,001$ \\
\hline & $(0,000)$ & $(0,000)$ & $(0,000)$ & & $(0,932)$ \\
\hline \multirow{2}{*}{ Kimya } & $0,001^{*}$ & $0,001^{*}$ & $0,001^{*}$ & & $0,001^{* *}$ \\
\hline & $(0,005)$ & $(0,000)$ & $(0,000)$ & & $(0,022)$ \\
\hline \multirow{2}{*}{ Tekstil } & $0,001^{*}$ & $0,001^{*}$ & $0,001^{*}$ & & $-0,001 * *$ \\
\hline & $(0,001)$ & $(0,005)$ & $(0,000)$ & & $(0,015)$ \\
\hline \multirow{2}{*}{ Teknoloji } & $0,001^{*}$ & $-0,001 * *$ & $0,001 *$ & & $-0,001$ \\
\hline & $(0,000)$ & $(0,033)$ & $(0,000)$ & & $(0,363)$ \\
\hline Panel & $0,001^{*}$ & $0,001^{*}$ & $0,001^{*}$ & & $0,001 *$ \\
\hline FMOLS & $(0,000)$ & $(0,000)$ & $(0,000)$ & & $(0,003)$ \\
\hline
\end{tabular}

Parantez içindeki değerler, olasılık değerlerini göstermektedir.

* , ** ve ${ }^{* * *}$, sırasıyla $\% 1, \% 5$ ve $\% 10$ düzeylerinde anlamlılığı ifade etmektedir. 
Tablo 11 'de sunulan panel FMOLS sonuçlarına göre sanayi üretim endeksi ile Model 1, Model 2 ve Model 3 arasında negatif ve anlamlı ilişki varken Model 5 arasında ilişki tespit edilmemiştir.

Tablo 11: Sanayi Üretim Endeksi İçin Eşbütünleşme Katsayısı Tahmini

\begin{tabular}{|c|c|c|c|c|c|}
\hline Sektör & $\begin{array}{l}\text { Model } 1 \\
\text { (CAA) }\end{array}$ & $\begin{array}{c}\text { Model } 2 \\
\text { (ADH) }\end{array}$ & $\begin{array}{c}\text { Model } 3 \\
\text { (SDH) }\end{array}$ & $\begin{array}{l}\text { Model } 4 \\
\text { (NDS) }\end{array}$ & $\begin{array}{c}\text { Model } 5 \\
\text { (CO) }\end{array}$ \\
\hline Metal & $\begin{array}{l}1,001^{*} \\
(0,000)\end{array}$ & $\begin{array}{l}-0,258^{*} \\
(0,000)\end{array}$ & $\begin{array}{l}-0,187^{*} \\
(0,000)\end{array}$ & \multirow{7}{*}{ 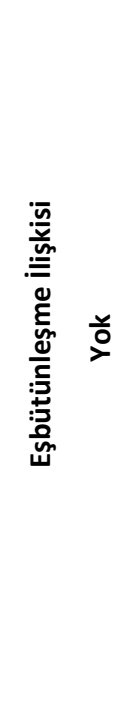 } & $\begin{array}{l}0,038 * \\
(0,000)\end{array}$ \\
\hline Gıda & $\begin{array}{c}0,375^{* * *} \\
(0,064)\end{array}$ & $\begin{array}{l}-0,379 * \\
(0,000)\end{array}$ & $\begin{array}{l}-0,228^{*} \\
(0,000)\end{array}$ & & $\begin{array}{c}0,012 \\
(0,385)\end{array}$ \\
\hline Kimya & $\begin{array}{c}-0,282 * * * \\
(0,062)\end{array}$ & $\begin{array}{l}-0,420^{*} \\
(0,000)\end{array}$ & $\begin{array}{l}-0,410^{*} \\
(0,000)\end{array}$ & & $\begin{array}{l}-0,019 \\
(0,178) \\
\end{array}$ \\
\hline Tekstil & $\begin{array}{c}-0,424 * * \\
(0,035) \\
\end{array}$ & $\begin{array}{l}-0,073 * \\
(0,003) \\
\end{array}$ & $\begin{array}{l}-0,062^{*} \\
(0,000)\end{array}$ & & $\begin{array}{l}0,039 * \\
(0,000)\end{array}$ \\
\hline Teknoloji & $\begin{array}{l}-0,430 * \\
(0,004)\end{array}$ & $\begin{array}{l}0,123 * \\
(0,000)\end{array}$ & $\begin{array}{l}-0,293^{*} \\
(0,000)\end{array}$ & & $\begin{array}{r}0,012 \\
(0,367)\end{array}$ \\
\hline Panel & $-0,148 * * *$ & $-0,201^{*}$ & $-0,175^{*}$ & & $-0,007$ \\
\hline FMOLS & $(0,052)$ & $(0,000)$ & $(0,000)$ & & $(0,267)$ \\
\hline
\end{tabular}

Parantez içindeki değerler, olasılık değerlerini göstermektedir.

$*, * *$ ve $* * *$, sırasıyla $\% 1, \% 5$ ve \%10 düzeylerinde anlamlılı̆̆ı ifade etmektedir.

Sanayi üretim endeksi ekonomideki üretim düzeyini göstermekle beraber sanayi üretim endeksinin artması üretimin artmasıyla, ekonomideki geleceğe yönelik belirsizliklerin azaldığı, tüketici güveninin arttığı, kredi koşullarında iyileşmenin olduğu, tüketim ve yatıım kararlarının olumlu yönde etkilendiği bir süreç olarak yorumlanabilir. Bu bağlamda düşünüldüğünde sanayi üretim endeksi işletmeler için öncü bir gösterge olmakta ve işletmelerin geleceğe yönelik beklentilerine yön vermektedir. Sanayi üretim endeksinin artması, işletme satışlarının artması ve buna bağlı olarak gelecekte elde edilmesi beklenen nakit akışlarının artması şeklinde yorumlanabilir. İşletmeler sanayi üretim endeksi arttı̆̆ında ekonomide genişleme olacağı düşüncesiyle satış ve satışa bağlı olarak stok miktarını artırmaktadır. Ayrıca işletmelerin sanayi üretim endeksini öncü gösterge kabul edip satışların ve siparişlerin artacağı beklentisiyle alacakların tahsilinde esnek bir politika izlendiği yorumu yapılabilir. Sanayi üretim endeksi ile Model 2 ve Model 3 arasındaki negatif ilişkiyi böyle yorumlamak mümkündür. 


\section{Sonuç}

Bu çalışmada, temel makroekonomik göstergelerin metal ana eşya, gıda, kimya, tekstil ve teknoloji sektörlerinin işletme sermayesi üzerindeki etkisi analiz edilmiş ve sektörler arasında bir karşılaştırma yapılmıştır. Bu amaçla çalışmada BisT'te yer alan 5 sektörün 2003-2013 dönemi çeyrek dönemlik panel veri seti kullanılmıştır. Bu veri setine ilk aşamada panel birim kök testlerinden olan Levin, Lin ve Chu (2002, LLC), Im, Pesaran ve Shin (2003, IPS) ve ADF Fisher birim kök testleri uygulanarak serilerin durağanlıkları ölçülmüştür. İkinci aşamada, panel veri setinde yer alan bağımlı ve bağımsız değişkenler arasındaki uzun dönem eşbütünleşme ilişkisinin test edilmesinde Pedroni (1999 ve 2004) tarafından önerilen ve temel hipotezi "eş bütünleşme yoktur" şeklindeki panel eşbütünleşme testi uygulanmıştır. Üçüncü aşamada ise değişkenler arasında uzun dönem eşbütünleşme ilişkisinin varlığı tespit edildikten sonra açıklayıcı değişkenlere ait uzun dönem katsayıların tahmini Pedroni (2000) tarafından geliştirilen Grup Ortalama Panel Tam Uyarlanmış En Küçük Kareler (FMOLS) yöntemi ile yapılmıştır.

İ̧̧letme sermayesi düzeyi sektörlerin yapısı itibariyle her sektörde farklılık göstermekte ve ekonomik değişmelere farklı tepkiler verebilmektedir. Çünkü makroekonomik koşulların işletme sermayesi yatırımları üzerindeki etkisinin büyüklüğü, sektörden sektöre değişmekte ve sektörler bu değişimlere farklı büyüklüklerde ve hızlarda tepkiler verebilmektedir. Çalışma sonucunda, temel makroekonomik göstergeler ile kurgulanan 5 modelden sadece Nakit Dönüşüm Süresi (Model 4) uzun dönem eşbütünleşme ilişkisi tespit edilmemiştir. Diğer dört modelde (dönen varlık/aktif toplamı, alacak devir hızı, stok devir hızı ve cari oran) uzun dönem eşbütünleşme ilişkisi bulunmuştur. Çalışmanın bulgularına göre makroekonomik göstergelerin işletme sermayesi üzerine etkisinin büyüklüğü, sektörden sektöre değişebilmekte ve değişen koşullara farklı sektörlerde farklı tepkiler verilebilmektedir. Yapılan tüm bu değerlendirmeler sonucunda, çalışmanın temel konusunu oluşturan makroekonomik göstergelerin sektörlerin işletme sermayesi üzerine etkisinin olduğu, yapılan analizlerden elde edilen sonuçlarla tespit edilmiştir. Firmaların işletme sermayesi yatırım ve finansman politikaları oluştururken, bu durumu göz önünde bulundurmaları likidite ve kârlılık dengesi açısından önem arz etmektedir. Ayrıca, enflasyon, faiz oranı ve döviz kuru gibi makroekonomik değişkenler, işletmelerin uzun vadeli yatırım ve üretim kararları alırken planlama ufkunu daraltmakta veya genişletmektedir. Bu açıdan, özellikle politika yapıcıları tarafından, sürdürülebilir bir ekonomik büyüme için sözkonusu değişkenlerin işletmelerin planlama ufkunu genişletici şekilde yönetilmesi ve değerlendirilmesi gerekmektedir.

Çalışmanın bulguları, literatürde daha önce yapılan bazı çalışmaların (Nazir ve Afza, 2009; Zariyawati, Taufig, Annuar vd., 2010; Mathuva, 2010; Karaduman, Akbaş, Özsözgün vd., 2010) bulguları ile benzerlik gösterirken; bazı çalışmaların (Cabellero, 
Teruel ve Solano, 2010; Manoori ve Muhammad, 2012) bulgularıyla da farklılık göstermektedir.

Bu çalışmada temel makroekonomik göstergeler esas alındığı için yapılacak çalışmalar farklı makroekonomik göstergelerle veya işletme sermayesi unsurları ile desteklenip zenginleştirilebilir. İşletme sermayesi düzeyinin belirleyicileri olarak hem makroekonomik değişkenlere hem de sektöre özgü değiş̧kenlere odaklanılabilir. Ayrıca eşbütünleşme ilişkisinin tespit edilemediği nakit dönüşüm süresinin uzun dönemde nasıl bir seyir izlediği ve her sektör için optimal bir nakit dönüşüm süresi düzeyinin var olup olmadığı araştırılabilir. 


\section{Kaynakça}

Afza, T. ve M. S. Nazir (2008), “Working Capital Approaches and Firm's Returns in Pakistan”, Pakistan Journal of Commerce and Social Sciences, Vol. 1, 25-36.

Aygün, M. (2012), “Firma Performansı Üzerinde Çalışma Sermayesinin Etkisi: Türk İmalat Sektörü Üzerine Bir Uygulama”, Ege Akademik Bakış Dergisi, 12(2), 215-223.

Brigham, F. E. ve J. F. Houston (2007), Fundamentals of Financial Management, $11^{\text {th }}$ Ed., USA: Thomson South-Western.

Büyükşalvarcı A. ve H. Abdioğlu (2010), “Kriz Öncesi ve Kriz Dönemlerinde İşletmelerde Çalışma Sermayesi Gereksiniminin Belirleyicileri: IMKB İmalat Sanayi Şirketleri Üzerine Ampirik Bir Uygulama", Atatürk Üniversitesi İktisadi ve İdari Bilimler Dergisi, 24(2), 4771.

Caballero, S. B., P. J. G. Teruel ve P. M. Solano (2010), “Working Capital Management in SMEs", Accounting and Finance, 50, 511-527.

Chiou, J-R., L. Cheng ve H-W. Wu (2006), "The Determinants of Working Capital Management", The Journal of American of Business, 10(1), 149-156.

Çakır, M, H. ve İ. Küçükkaplan (2012), "İşletme Sermayesi Unsurlarının Firma Değeri ve Kârlılığı Üzerindeki Etkisinin iMKB'de İşlem Gören Üretim Firmalarında 2000-2009 Dönemi İçin Analiz", Muhasebe ve Finansman Dergisi, 53, 69-86.

Çakır, M, H. (2013), "Nakit Döngüsünün Firma Kârlılığına Etkisini Sektörel Analizi”, Journal of Yaşar University, 30(8), 4948-4965.

Coşkun, E. ve D. Kök (2011), “Çalışma Sermayesi Politikalarının Kârlılık Üzerine Etkisi: Dinamik Panel Uygulaması”, Ege Akademik Bakış Dergisi, 11, 75-85.

Deloof, M. (2003), “Does Working Capital Management Affect Profitability of Belgian Firms?", Journal of Business Finance and Accounting, 30(3/4), 573-587.

Dursun, A. ve Y. Ayrıçay (2012), "Çalışma Sermayesi-Kârlılık İlişkisinin IMKB Örneğinde 1996-2005 Dönemi Analizi”, Atatürk Üniversitesi İktisadi ve İdari Bilimler Dergisi, 26(34), 199-215.

Eljelly, A. M. (2004), "Liquidity - Profitability Tradeoff an Empirical Investigation in an Emerging Market", International Journal of Commerce and Management, $14(2), 48-61$.

Fazzari, M.,S ve B. C. Petersen (1993), “Working Capital and Fixed Investment: New Evidence on Financing Constraints", The RAND Journal of Economics, 24(3), 328-342.

Filbeck, G. ve T. M. Krueger (2005), “An Analysis of Working Capital Management Results across Industries", Mid-American Journal of Business, 20 (2), 11-18. 
Gill, A. (2011), "Factors That Influence Working Capital Requirements in Canada", Economics and Finance Review, 1(3), 30-40.

Gill, A., N. Biger ve N. Mathur (2010), "The Relationship between Working Capital Management and Profitability: Evidence from The United States", Business and Economics Journal, 10, 1-9.

Hill, M. D., G. W. Kelly ve M. J. Highfield (2010), "Net Operating Working Capital Behavior: A First Look", Financial Management, 39(2), 783-805.

Im, Pesaran ve Shin (2003), "Testing for Unit Roots in Heterogeneous Panels", Journal of Econometrics, 115, 53-74.

Işık, E. ve M. Kiracı (2012), "2008 Küresel Finansal Krizin İşletmelerin Çalışma Sermayeleri Üzerindeki Etkilerinin Oranlar Aracılı̆̆ıyla Tespiti: IMKB'de Bir Araştırma", Muhasebe ve Finansman Dergisi, 54, 157-174.

Jose, M. L., C. Lancaster ve J. L. Stevens (1996), "Corporate Returns and Cash Conversion Cycles", Journal of Economics and Finance, 20(1), 33-46.

Karaduman, H. A., H. E. Akbaş, A. Özsözgün ve S. Durer (2010), "Effects of Working Capital Management on Profitability: The Case For Selected Companies in The İstanbul Stock Exchange (2005-2008)", International Journal of Economics and Finance Studies, 2(2), 47-54.

Kolb, B. ve R. F. DeMong (1988), Principles of Financial Management, $2^{\text {nd }}$ Ed., Texas: Business Publications, Inc.

Kök, D., E. Coşkun ve M. S. İspir (2013), "Çalışma Sermayesi Politikalarında Sektörel Farklılaşma ve Ortalamaya Dönme Eğilimi", Business and Economics Research Journal, $4(4), 49-70$.

Lazaridis, I. ve D. Tryfonidis (2006), "Relationship between Working Capital Management and Profitability of Listed Companies in the Athens Stock Exchange", Journal of Financial Management and Analysis, 19(1), 26-35.

Levin, Lin ve Chu (2002), "Unit Root Tests in Panel Data: Asymptotic and Finite-sample Properties", Journal of Econometrics, 108(1), 1-24.

Maddala G.S., S. Wu (1999), "A Comparative Study of Panel Data Unit Root Tests and a Simple Alternative", Oxford Bulletin of Economics and Statistics, 61, 631-652

Manoori, E. ve J. Muhammad (2012), "Determinants of Working Capital Management: Case of Singapore Firms", Research Journal of Finance and Accounting, 3(11), 15-24.

Mathuva, D. M. (2010), "The Influence of Working Capital Management Components on Corporate Profitability: A Survey on Kenyan Listed Firms", Research Journal of Business Management, 4(1), 1-11. 
Nazir, M. S. ve T. Afza (2009), "Impact of Aggressive Working Capital Management Policy on Firms' Profitability", The IUP Journal of Applied Finance, 15(8), 19-30.

Omağ, A. (2009), “Gıda Sektöründe Nakit Dönüşüm Süresi Analizi: Türkiye ve Amerika Birleşik Devletleri Örneği", Maliye Finans Yazıları, 23(83), 45-58.

Öz, Y. ve B. Güngör. (2007), “Çalışma Sermayesi Yönetiminin Firma Karlılığı Üzerine Etkisi: İmalat Sektörüne Yönelik Panel Veri Analizi", Atatürk Üniversitesi Sosyal Bilimler Enstitüsü Dergisi, 10(2), 319-332.

Öztürk, M. B. ve K. Demirgüneş (2008), "İ̧̧letme Sermayesi Gereksinimini Etkileyen Değişkenler Üzerine iMKB'de Bir Uygulama”. Finans Politik \& Ekonomik Yorumlar, 45(516), 47-56.

Padachi, K. (2006), "Trends in Working Capital Management and Its Impact on Firms' Performance: An Analysis of Mauritian Small Manufacturing Firms", International Review of Business Research Papers, 2(2), 45-58.

Pedroni, P. (1999), "Critical Values for Cointegrating Tests in Heterogeneous Panels with Multiple Regressors", Oxford Bulletin of Economics and Statistics, 61(1), 653-570.

Pedroni, P. (2000), "Fully Modified OLS for Heterogeneous Cointegrated Panels", Department of Economics Working Papers, No: 2000-03, Department of Economics, Williams College.

Pedroni, P. (2001), "Purchasing Power Parity Tests in Cointegrated Panels", Review of Economics and Statistics, 83(4), 727-931.

Pedroni, P. (2004), "Panel Cointegration, Asymptotic and Finite Sample Properties of Pooled Time Series Tests with an Application to the Purchasing Power Parity Hypothesis", Econometric Theory, 20(3), 597-625.

Raheman, A. ve M. Nasr (2007), “Working Capital Management and Profitability - Case of Pakistani Firms", International Review of Business Research Papers, 3(1), 279-300.

Ramachandran, A. ve M. Janakiraman (2009), "The Relationship between Working Capital Management Efficiency and EBIT", Managing Global Transitions, 7(1), 61-74.

Shin, H. H. ve L. Soenen (1998), "Effciency of Working Capital Management and Corporate Profitability", Financial Practice and Education, 8(2), 37-45.

Şamiloğlu, F. ve K. Demirgüneş (2008), "The Effect of Working Capital Management on Firm Profitability: Evidence from Turkey", The International Journal of Applied Economics and Finance, 2(1), 44-50.

Şen, M. ve E. Oruç (2009), "Relationship between Efficiency Level of Working Capital Management Return on Total Assets in ISE", International Journal of Business and Management, 4(10), 109-114. 
Şen, M. F. M. Baştürk ve E. Oruç (2009), “iMKB’de Faaliyet Gösteren Firmalarda 19922007 Dönemi İçin İşletme Sermayesinde Yönetim Etkinliğinin Ölçümü ve Genel Değerlendirme" 13. Ulusal Finans Sempozyumu, 21-24 Ekim 2009, Ayfonkarahisar, 137-148.

Teruel P. G. ve P. M. Solano (2007), "Effects of Working Capital Management on SME Profitability", International Journal of Managerial Finance, 3(2), 164-177.

Tomak, S. (2013), Çalışma Sermayesi Yönetimi (Türkiye İmalat Sektöründe Çalışma Sermayesi Uygulamaları ve Firma Performansına Etkisi), Ankara: Detay Yayıncılık.

Ukaegbu, B. (2014), "The Significance of Working Capital Management in Determining Firm Profitability: Evidence from Developing Economies in Africa", Research in International Business and Finance, 31, 1-16.

Uyar, A. (2009), "The Relationship of Cash Conversion Cycle with Firm Size and Profitability: An Empirical Investigation in Turkey", International Research Journal of Finance and Economics, 24, 186-193.

Vural, G., A. G. Sökmen ve E. H. Çetenak (2012), "Affects of Working Capital Management on Firm's Performance: Evidence from Turkey", International Journal of Economics and Financial Issues, 2(4), 488-495.

Yücel, T. ve G. Kurt (2002), “Nakit Dönüş Süresi, Nakit Yönetimi ve Kârlılık: IMKB Şirketleri Üzerinde Ampirik Bir Çalışma", iMKB Dergisi, 6(22), 1-15.

Weinraub H.J. ve S. Vjsscher (1998), "Industry Practice Relating to Aggressive Conservative Working Capital Policies", Journal of Financial and Strategic Decision, 11(2), 11-18.

Wu, C. ve S. J. K. Ho (1997), "Financial Ratio Adjustment: Industry-Wide Effects or Strategic Management", Review of Quantitative Finance and Accounting, 9(1), 71-88.

Zariyawati, M. A., H. Taufiq, M. N. Annuar ve A. Sazali (2010), "Determinants of Working Capital Management: Evidence from Malaysia", 2010 International Conference on Financial Theory and Engineering, 190-194. 